\title{
NETWORK NEUTRALITY AND THE FALSE PROMISE OF ZERO-PRICE REGULATION
}

\author{
C. Scott Hemphill ${ }^{\dagger}$
}

This Article examines zero-price regulation, the major distinguishing feature of many modern "network neutrality" proposals. A zero-price rule prohibits a broadband Internet access provider from charging an application or content provider (collectively, "content provider") to send information to consumers. The Article differentiates two access provider strategies thought to justify a zero-price rule. Exclusion is anticompetitive behavior that harms a content provider to favor its rival. Extraction is a toll imposed upon content providers to raise revenue. Neither strategy raises policy concerns that justify implementation of a broad zero-price rule. First, there is no economic exclusion argument that justifies the zero-price rule as a general matter, given existing legal protections against exclusion. A stronger but narrow argument for regulation exists in certain cases in which the output of social producers, such as Wikipedia, competes with ordinary market-produced content. Second, prohibiting direct extraction is undesirable and counterproductive, in part because it induces costly and unregulated indirect extraction. I conclude, therefore, that recent calls for broad-based zero-price regulation are mistaken.

\footnotetext{
† Associate Professor and Milton Handler Fellow, Columbia Law School. Larry Darby, Brett Frischmann, Victor Goldberg, Harvey Goldschmid, Jeffrey Gordon, Robert Hahn, Michael Heller, Bert Huang, Kenneth Katkin, William Kovacic, Ilyana Kuziemko, Mark Lemley, Christopher Leslie, Lawrence Lessig, Lance Liebman, Edward Morrison, Richard Posner, Alex Raskolnikov, Robert Scott, Philip Weiser, Mark Wu, and Tim Wu, and participants in conferences at the University of Colorado (Boulder), the Max Planck Institute for Research on Collective Goods, and Michigan State University, provided helpful discussion and comments on previous drafts. Melanie Brown, Jessie Cheng, Matt Dobbins, and Doug Geyser provided outstanding research assistance.
} 
Introduction

I. Justifying Zero-Price Regulation...................................................... 140

A. An Example: The AT\&T Merger Condition............................... 140

1. Means: Zero-Price Regulation ............................................... 140

2. Ends: "Anticompetitive Discrimination" and "Toll Booths"

B. The Potential Costs of Access Control ....................................... 145

1. Exclusion and Reduced Competition..................................... 146

2. Extraction and Reduced Innovation.......................................... 148

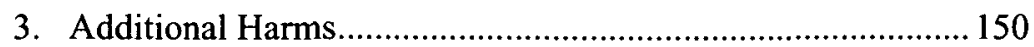

C. The Consequences of Conflation ................................................ 151

II. Reconsidering Exclusion ............................................................. 152

A. Identifying Gaps in Antitrust Law ........................................... 153

B. The Vonage Gap: Refusing to Deal with a Legacy Business

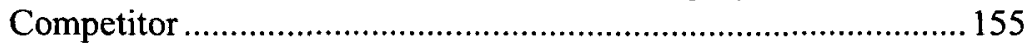

1. Fragmentation of Access Provision ....................................... 156

2. Existing Antitrust Prohibitions .............................................. 157

C. The Wikipedia Gap: Exclusion of Social Production ................... 160

1. Distinctive Features of Social Production.............................. 160

2. Mechanism of Exclusion ..................................................... 161

3. Limited Feasibility of Regulation ......................................... 162

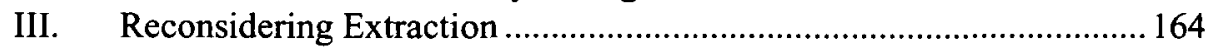

A. The Indirect Extraction Problem................................................. 166

B. Nonfinancial Incentives to Develop Content ................................. 169

C. Extraction as a Means to Increase Consumer Spillovers ...............171

D. Contracting into Decentralized Innovation ...................................173

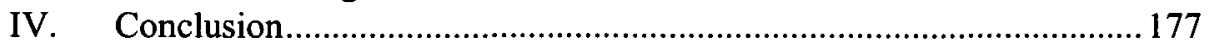

Introduction

The modern debate about regulatory policy in telecommunications elicits a powerful sense of déjà vu. Recent proposals for "network neutrality" regulation echo and invoke common carriage, the regulatory regime often applied to railroads, telecommunications, and other infrastructural industries. The central requirement of common carriage is that the carrier must offer its services in a nondiscriminatory fashion. ${ }^{1}$ Network neutrality, like common carriage, responds to a concern that the owner of a bottleneck facility-here, a

1 For an introduction to nondiscrimination norms in common carrier regulation, see Joseph D. Kearney \& Thomas W. Merrill, The Great Transformation of Regulated Industries Law, 98 COLUM. L. REV. 1323, 1330-40 (1998). For arguments that network neutrality is simply a replay of common carriage, see infra note 18 and accompanying text. 
broadband Internet access provider-will discriminate among users of the facility in a socially undesirable fashion. ${ }^{2}$ The users at issue are a wide range of content and application providers, from YouTube and Yahoo to firms such as Vonage that provide telephone service over a broadband connection, users that I refer to collectively as "content providers."

The analogy to common carriage, however, is imperfect. Network neutrality departs from the traditions of common carriage in an important respect. Many (though not all) network neutrality proposals share a distinctive feature, what I call a zero-price rule. A zero-price rule prohibits an access provider from charging content providers to send information to consumers. ${ }^{3}$ For example, access provider AT\&T may not charge video content provider YouTube for access to AT\&T's customers, even if AT\&T makes the same offer to YouTube rivals such as iFilm. A zero-price rule has significant economic consequences due to the emergent capacity of an access provider to control the ability of content providers to reach broadband customers. ${ }^{4}$ Requiring a uniform, zero price exceeds the restrictions of common carriage, which tolerates some forms of price discrimination in which an offer available to one purchaser is also available to others.

This Article poses and answers a single question: can zero-price regulation of broadband access providers be justified on economic grounds? The first step of the analysis is to distinguish two access provider strategies that might justify the rule. These strategies are not unique to broadband access providers, but are available generally to any provider of a platform-that is, a foundational technology such as broadband access, the electric grid, or a video game console, used in combination with particular complementary applications to deliver value to consumers. ${ }^{5}$ The analysis presented here thus provides insight into the broader question of optimal regulation of platforms.

The first platform strategy is exclusion: actions taken to impair an application's success relative to its rival. For example, in exchange for compensation from YouTube, AT\&T might favor YouTube over iFilm in order to induce iFilm's exit. The second strategy is extraction: a platform's threat of

2 For a useful summary of the debate, see Jon M. Peha et al., The State of the Debate on Network Neutrality, 1 INT'L J. COMM. 709 (2007).

3 The content provider makes payments for transport but makes no incremental payment to the consumer's broadband provider. See infra Section I.A for further discussion.

4 See FTC, BROADBAND CONNECTIVITY COMPETITION POLICY 30-31 (2007), available at http://www.ftc.gov/reports/broadband/v070000report.pdf [hereinafter FTC STAFF REPORT] (describing packet inspection and "flow classification" technologies that enable inferences about packet type and SOUrCe); ORGANISATION FOR ECONOMIC CO-OPERATION AND DEVELOPMENT, INTERNET TRAFFIC PRIORITISATION: AN OVERVIEW (2007), available at http://www.oecd.org/dataoecd/43/63/38405781.pdf (discussing tools to inspect packets, discern their type, and prioritize their delivery).

5 For related definitions of a platform, see Timothy F. Bresnahan \& Shane Greenstein, Technological Competition and the Structure of the Computer Industry, 47 J. INDUS. ECON. 1 (1999); Annabelle Gawer \& Rebecca Henderson, Platform Owner Entry and Innovation in Complementary Markets: Evidence from Intel, 16 J. ECON. \& MGMT. STRATEGY 1 (2007); Jean-Charles Rochet \& Jean Tirole, Two-Sided Markets: A Progress Report, 37 RAND J. ECON. 645 (2006). 
exclusion, made to all applications in order to expropriate a share of application profits. For example, AT\&T might insist upon payments from both YouTube and iFilm in exchange for premium access.

Both exclusion and extraction rely upon the platform's ability to control access to its consumers, but differ in the use to which that power is put. A platform's incentive to extract, unlike its incentive to exclude, is premised upon application success, because successful applications present a larger opportunity for extraction. Extraction entails a threat of exclusion, but the threat is unlikely to be implemented because the parties will reach a bargain instead. Extraction is a form of private taxation that aims to raise revenue, rather than-as with exclusion-taxation to deter disfavored behavior. Although the separation is imperfect, exclusion is a preoccupation of antitrust policy. Extraction is not generally a subject of antitrust, but it is a central concern of innovation policy because the transfer of resources from applications to the platform may alter the prospective incentives of each to invest in innovation.

One contribution of this Article is to untangle exclusion and extraction as distinct bases for zero-price regulation. These differences are frequently ignored, producing an unfortunate conflation of justifications for regulation. Separating the two permits a reframing of the key question: to what extent do exclusion or extraction concerns justify the imposition of a zero-price rule upon access providers? To answer that question, the present analysis focuses attention on key elements of industry economics, such as fragmentation in the access provider market, nonfinancial incentives to develop content, and market interactions among content providers, consumers, and access providers that undo the effect of a regulatory intervention.

An initial result is that exclusion concerns provide no general justification for a zero-price rule. Much anticompetitive exclusion is already prohibited by existing antitrust law. To the extent that antitrust law as currently enforced successfully identifies and remedies exclusion, there is less need for a new layer of regulatory intervention. A zero-price rule is also overinclusive, relative to concerns about exclusion. Thus, advocates who rely upon exclusion to justify broad zero-price rules are mistaken.

There is a relatively stronger argument for zero-price regulation, however, in the narrower case of socially produced content-that is, content such as the online encyclopedia Wikipedia, produced when individuals collaborate without anticipation of financial reward. ${ }^{6}$ Socially produced content raises distinctive issues for regulatory policy where such content competes with ordinary marketproduced content. For example, Wikipedia vies with market competitors such as Encyclopedia Britannica for the attention of broadband customers. Exclusion of social production is a source of inefficiency that antitrust law is unlikely to

6 See Yochai Benkler, The Wealth of Networks: How Social Production TRANSFORMS MARKETS AND FREEDOM 59-90 (2006) (describing social production of content). 
remedy. Reducing that inefficiency is a possible, albeit narrower, mission for zero-price regulation.

Extraction concerns fare no better, in general, as a justification for a zeroprice rule. Zero-price rules have a serious practical problem. Although an access provider is prohibited from charging content providers, it is free to charge consumers under the leading network neutrality proposals. As a result, the access provider may charge the consumer for premium service-prompt delivery of video, for example-in the expectation that the content provider, in turn, will compensate the consumer for the extra expense. When indirect extraction replaces (prohibited) direct extraction, private bargaining tends to undo the effect of the government regulation. The shift to indirect extraction also imposes a social cost, making a ban on direct extraction not only ineffective, but counterproductive as well.

Extraction is a doubtful basis for a zero-price rule for other reasons. Internet content is often developed for reasons other than the expectation of profit. To the extent that nonfinancial motivations spur content development, extraction matters less for content development than is generally assumed. Moreover, consumer usage of broadband service may create significant benefits that are not captured by the access provider or content provider. An access provider strategy to charge content providers, while subsidizing consumers with low financial willingness to pay, could increase adoption and thereby increase these benefits. This attractive strategy is forbidden by a zeroprice rule. In sum, neither exclusion nor extraction concerns justify a broad zero-price rule.

Part I of this Article defines a zero-price rule, distinguishes exclusion- and extraction-based justifications for zero-price regulation, and identifies several harms that have resulted from the conflation of these justifications. Part II considers and rejects exclusion as a justification for a generally applicable zero-price rule, while identifying a stronger argument for narrowly focused regulation where socially produced content competes with market production. Part III explains why extraction concerns provide no clear justification for a zero-price rule. Part IV concludes.'

7 To focus attention on the issues discussed in the text, much is omitted. This Article is not a comprehensive treatment of common carriage, platform economics, or network neutrality. For example, I focus upon the scope of substantive prohibition but do not venture far into the relative institutional merits of ex ante regulation and ex post antitrust intervention. For an introduction to this debate, compare PETER HUBER, LAW AND DISORDER IN CYBERSPACE 3-9 (1997) (advocating abolition of FCC and maintenance of competition through common law, particularly antitrust law), with Robert $D$. Atkinson \& Philip J. Weiser, A Third Way on Network Neutrality, NEW ATLANTIS, Summer 2006, at 47, 56 (advocating FCC oversight of competition). See also Joseph Farrell, Open Access Arguments: Why Confidence Is Misplaced, in NET NEUTRALITY OR NET NEUTERING: SHOULD BROADBAND INTERNET SERVICES BE REgUlATED? 195, 206 (Thomas M. Lenard \& Randolph J. May eds., 2006) (noting the difficulty of ex post antitrust intervention); Howard A. Shelanski, Adjusting Regulation to Competition: Toward a New Model for U.S. Telecommunications Policy, 24 YALE J. ON REG. 55, 101-02 (2007) (favoring ex post, targeted enforcement over ex ante regulation). I mention but do not dwell upon certain effects of price discrimination whose applicability is contested in this context-for example, that if a 


\section{Justifying Zero-Price Regulation}

\section{A. An Example: The AT\&T Merger Condition}

In 2006, AT\&T announced its plan to acquire BellSouth, the latest step in a continuing consolidation among local telephone companies. ${ }^{8}$ In addition to providing ordinary telephone service, the merged entity possessed a substantial broadband access business. The Antitrust Division of the Department of Justice approved the deal without imposing any conditions. ${ }^{9}$ The Federal Communications Commission (FCC), whose approval was also required, took a different approach. Two commissioners with a collective veto over the AT\&T-BellSouth transaction, ${ }^{10}$ Commissioners Adelstein and Copps, obliged the parties to accept a network neutrality condition in December 2006. An examination of the merger condition and the justifications given by the FCC commissioners highlights a leading form of network neutrality regulation, namely zero-price regulation, and the disparate ends it is thought to serve.

\section{Means: Zero-Price Regulation}

The AT\&T merger condition is a zero-price rule in the sense discussed in the introduction. It forbids AT\&T to "provide" or "sell" to content providers "any service that privileges, degrades or prioritizes any packet ... based on its source, ownership or destination." the "best-efforts" service that characterizes ordinary Internet access provision, a distinct high-quality offering providing access to (say) YouTube-for example, service with less transmission delay ("latency") or variation in transmission speed ("jitter"), qualities that are useful for delivering real-time

tailored offering is prohibited, output might fall, and that price discrimination is a useful tool for efficiently managing congestion. Noneconomic justifications for regulation, including the First Amendment and equality norms, are slighted too. Compare Bill D. Herman, Opening Bottlenecks: On Behalf of Mandated Network Neutrality, 59 FED. COMM. L.J. 107, 116-23 (2006) (advocating neutrality as means to diversify editorial control), with Christopher S. Yoo, Network Neutrality and the Economics of Congestion, 94 GEO. L.J. 1847, 1905-08 (2006) (opposing neutrality as interference with editorial discretion).

8 See Bell Atl. Corp. v. Twombly, 127 S. Ct. 1955, $1961-62$ \& n.1 (2007) (describing creation and consolidation of incumbent local exchange carriers).

9 Press Release, U.S. Dep't of Justice, Statement by Assistant Attomey General Thomas O. Barnett Regarding the Closing of the Investigation of AT\&T's Acquisition of BellSouth (Oct. 11, 2006), available at http://www.usdoj.gov/atr/public/press_releases/2006/218904.pdf.

10 The approval of a majority of the five-member Commission was required, and after one commissioner withdrew from consideration of the merger, see Jim Puzzanghera, FCC Approves AT\&T Merger, L.A. Times, Dec. 30, 2006, at C1, Commissioners Copps and Adelstein collectively held a blocking veto.

11 Letter from Robert W. Quinn, Jr., Senior Vice President, AT\&T Servs., Inc., to Marlene H. Dortch, Sec'y, FCC 8 (Dec. 28, 2006), available at http://www.fcc.gov/ATT_FINALMerger Commitments12-28.pdf [hereinafter AT\&T Merger Condition]. 
video content. ${ }^{12}$ Aside from prohibiting AT\&T from making a premium deal with YouTube alone, the merger condition prohibits AT\&T from making a premium offer generally available to all video content providers-that is, not only to YouTube but also to its rivals, such as iFilm. ${ }^{13}$ In fact, AT\&T is barred even from charging all content providers a uniform, fixed fee. ${ }^{14}$

To be clear, even if a content provider is insulated from the access payments that are the subject of this Article, the content provider must pay its own access provider for connectivity. ${ }^{15}$ Thus, a zero-price rule imposes a zero price only as to the incremental charge made by the consumer's access provider to connect a particular content provider with the consumer.

The imposition of a zero, uniform price crosses the traditional boundaries of common carriage. Common carriage is a frequent source of analogies and reasoning for modern telecommunications policy. ${ }^{16}$ Because access providers are not subject to common carrier rules, ${ }^{17}$ it is natural to ask whether commoncarrier regulation should extend to access provision. Some commentators view network neutrality as a replay of the common carriage debate. ${ }^{18}$

The price uniformity implemented by a zero-price rule, however, is not a condition of common carriage. Common carriers have long been permitted to

12 An access provider might exercise control by blocking certain content entirely, or instead by altering its speed, latency, or jitter. For some types of content, only a block will have an economic effect. The present analysis is insensitive to the precise method used to impose the relative disadvantage, and ventures no view about whether blockıng raises additional concerns on noneconomic grounds, such as the First Amendment. Cf. Red Lion Broad. Co. v. FCC, 395 U.S. 367, 392 (1969) (affirming FCC policy designed to prevent "private censorshıp").

13 Such an offer, if accepted, would "privilege" service based upon a packet's "source." AT\&T Merger Condition, supra note 11 , at 8 . The condition applies to offers made to AT\&T subsidiaries and lasts for two years or until Congress passes network neutrality legislation, whichever comes first. AT\&T's willingness to accept a relatively short-lived restriction may reflect a calculation that discrimination is not yet fully practicable.

14 Charging a provider for basic service would once again "privilege" service based upon a packet's "source." See id.

15 See, e.g., Lawrence Lessig, Address at the American Enterprise Institute: Key Issues in Telecommunications Policy 29:50 (May 10, 2006), available at http://app2.capitalreach.com/esp 1204/ servlet $/ \mathrm{tc} ? \mathrm{cn}=\mathrm{ae} i \& \mathrm{c}=10162 \& \mathrm{~s}=20272 \& \mathrm{e}=2921 \& \&$ espmt $=2$ [hereınafter Lessig AEI Presentation] (noting content provider payments for connectivity).

16 See generally ITHIEL DE SOLA POOL, TeChNOLOGIES OF FreEdom (1983).

17 See Nat'l Cable \& Telecomms. Ass'n v. Brand X Internet Servs., 545 U.S. 967 (2005) (affirming FCC determination that cable modem access is not telecommunications service subject to common carrier requirements); In re Appropnate Framework for Broadband Access to the Internet over Wureline Facilities, 20 F.C.C.R. 14,853 (2005) (forbearing to impose common carrier requirements upon DSL broadband access providers, despite their status as a telecommunications service).

18 See, e.g., Bruce Owen, The Net Neutrality Debate: Twenty Five Years After United States v. AT\&T and 120 Years After the Act to Regulate Commerce 4 \& n.6 (Stanford Law \& Econ. Olin Working Paper No. 336, 2007), available at http://ssm.com/abstract=963623 (describing net neutrality as a "semantically unnecessary term for the old ide[a] 'common carrier access"'); Christian Sandvig, Network Neutrality Is the New Common Carriage, 9 J. POL'Y, REG. \& STRATEGY 136 (2007); Moyers on America: The Net at Risk (PBS television broadcast Oct. 18, 2006) (transcript available at http://www.pbs.org/moyers/moyersonamerica/print/netatrisk_transcript_print.html) (quoting Rick Karr, reporter for documentary; "The Internet version of common carriage is known as 'network neutrality."'). 
engage in price discrimination. Historically, for example, railroads have charged a higher price to shippers of high-value materials, ${ }^{19}$ as part of value-ofservice ratemaking. ${ }^{20}$ Telephone companies charged higher rates to business customers and in large cities. ${ }^{21}$ And highly tailored service packages for large business customers have been held to satisfy the Communication Act's nondiscrimination rule, ${ }^{22}$ provided the filed tariff is available to other customers with the same needs. ${ }^{23}$ Common carriage merely prohibits certain types of unreasonable discrimination. ${ }^{24}$ Network neutrality therefore adds an additional element-insistence upon a zero, uniform price-to the traditional regulatory principles of nondiscrimination and interconnection.

Though not a requirement of common carriage, some regulatory regimes do implement a zero-price rule. The Carterfone attachment regime permitted independent equipment manufacturers to offer new attachments to the AT\&T network without permission from or payment to AT\&T. ${ }^{25}$ "Must-carry" rules require cable television providers to carry local television broadcasts without payment. ${ }^{26}$ Zero-price outcomes are implemented outside the context of communications as well. For example, the owners of the electric grid charge end users but not appliance manufacturers, though this appears to be a matter of technical feasibility rather than the result of any legal rule.

A zero-price rule is a key tenet of network neutrality advocacy. Aside from the AT\&T merger condition, it is a common feature of proposed

19 See, e.g., James C. Bonbright, PrinCiPles of Public Utility Rates 83 (1961) (railroad rates vary depending upon value of commodity shipped, out of proportion to difference in cost).

20 See id. at 372 (describing Interstate Commerce Commission approval of value-of-service ratemaking despite discriminatory effect). One source of confusion has been use of the term "discrimination" to denote only actionable discrimination. Id. at 371-72.

21 Id. at $83 ; 1$ ALFRED E. KAHN, THE ECONOMICS OF REgulation: PRINCIPLES AND INSTITUTIONS 63-64 (1970).

2247 U.S.C. § 202(a) (2000) (prohibiting "unjust or unreasonable discrimination").

23 For example, AT\&T's Tariff 12. See Competitive Telecomms. Ass'n v. FCC, 998 F.2d 1058, 1063 (D.C. Cir. 1993) ("[I]f the package is made available to any customer who wants it upon the same terms, then there is no unlawful discrimination."); see also Sea-Land Serv., Inc. v. ICC, 738 F.2d 1311,1317 (D.C. Cir. 1984) ("Although one normally regards contract relationships as highly individualized, contract rates can still be accommodated to the principle of nondiscrimination by requiring a carrier offering such rates to make them available to any [customer] willing and able to meet the contract's terms.").

24 See BONBRIGHT, supra note 19, at 370 (only "undue" or "unjust" discrimination prohibited); Eli M. Noam, Beyond Liberalization II: The Impending Doom of Common Carriage, 18 TELECOMM. POL'Y 435, 436 (1994) ("[N]o customer seeking service upon reasonable demand, willing and able to pay the established price, however set, would be denied lawful use of the service or would otherwise be discriminated against.") (emphasis added); id. at 438 (noting that limitations on discrimination are not absolute); see also James B. Speta, A Common Carrier Approach to Internet Connection, 54 FED. COMM. L.J. 225, 258 (2002) (noting the weakness of the nondiscrimination obligation at common law).

25 Provided the attachment meets certain minimum technical requirements. In re Use of the Carterfone Device in Message Toll Tel. Servs., 13 F.C.C.2d 420 (1968), reconsideration denied, 14 F.C.C.2d 571 (1968).

2647 U.S.C. $\S \S 534,535$ (2000) (cable); see also id. § 338(a)(1) (Supp. V 2005) (similar for direct broadcast satellite operators). 
legislative solutions, ${ }^{27}$ academic advocacy, ${ }^{28}$ and corporate lobbying by content providers such as Google. ${ }^{29}$ Opponents of network neutrality have identified it as a troubling feature of regulatory proposals. ${ }^{30}$

Not all network neutrality proponents insist upon a zero-price rule. Others, including Lawrence Lessig ${ }^{31}$ and a senior Google executive (dissenting from the firm's official position), ${ }^{32}$ appear to accept access fees imposed upon content providers, provided that an offer made to one content provider is also extended to its rivals. ${ }^{33}$

27 In early 2007, Senator Dorgan introduced the Internet Freedom Preservation Act, which would amend the Communications Act to impose a zero-price rule. S. 215, 110th Cong. $\S 2$ (2007) (adding a new section 12(a)(4)(C) to the Communications Act, imposing a duty upon carriers to enable application access on a basis that does not impose a charge on the basis of application type). In the 109th Congress, at least three bills employed a zero-price rule. Representative Sensenbrenner introduced the Internet Freedom and Nondiscrimination Act of 2006, which would have amended the Clayton Act to require an access provider to prioritize all data of a specific type, regardless of origin of ownership, if it did so for any data of that type, and without charging, and to provide nonaffilıated applications with the same quality (again without a charge) as that provided to affiliates. H.R. 5417, 109th Cong. $\$ 3(2006)$. The Network Neutrality Act of 2006, introduced by Representative Markey, would have imposed a similar duty. H.R. 5273, 109th Cong. $\S 4(a)(7)$ (2006) ("[lf a] broadband network provider prioritizes ... data of a particular type, [then it must] prioritize ... all data of that type (regardless of [origin]) without imposing a surcharge ...."). Of similar import was the Internet Non-Discrimination Act of 2006 introduced by Senator Wyden. S. 2360, 109th Cong. \& 4(a)(3) (2006) (" $[$ A] network operator shall ... not assess a charge to any application or service provider not on the network of such operator for the delivery of traffic to any subscriber to the network of such operator ....").

28 FTC, Broadband Connectivity Competition Policy Workshop 259-60 (Feb. 14, 2007), available at http://www.ftc.gov/opp/workshops/broadband/transcript_070214.pdf (statement of Tim Wu) (arguing in favor of zero-price regulation).

29 Posting of Richard Whitt, Washington Telecom and Media Counsel, to Google Public Policy Blog, http://googlepublicpolicy.blogspot.com/2007/06/what-do-we-mean-by-net-neutrality.html (June 16, 2007, 17:52 EST) (advocating ban on "surcharges on content providers that are not [the access provider's] retail customers").

30 See, e.g., Hal J. Singer, Net Neutrality: A Radical Form of Non-Discrimination, REG., Summer 2007, at 36; Robert W. Hahn \& Robert E. Litan, The Myth of Network Neutrality and What We Should Do About It 8-9 (AEI-Brookings Joint Ctr. for Regulatory Studies, Working Paper No. RP06-33, 2006), available at $\mathrm{http}: / / \mathrm{www}$.aei-brookings.org/admin/authorpdfs/page.php?id=1357.

31 See, e.g., Lessig AEI Presentation, supra note 15, at 1:04:20 (answering, in response to question, that charging Google and rival the same amount would not raise application tiering issues); $i d$. at 58:30 (stating that only concern is viewpoint discrimination); Lawrence Lessig, Lecture at Center for American Progress, The Withering of the Net: How D.C. Pathologies Are Undermining the Growth and Wealth of the Net 14 (June 16, 2006) (transcript available at http://www.americanprogress.org/kf/ 060616\%20lessig\%20lecture.pdf) (accepting practice where access provider charges rival content providers same premium price for video transport).

32 Google Senior Policy Counsel Andrew McLaughlin distinguished zero-price regulation, Google's official position, from a "more pragmatic view that it is OK [to charge] as long as it is done in a non-discriminatory way." See Posting of Drew Clark to GigaOM, Is Google Changing Its Position on Net Neutrality?, http://gigaom.com/2007/03/13/is-google-changing-its-position-on-net-neutrality (Mar. 13, 2007). A Google spokesperson later reaffirmed that McLaughlin's view differed from Google's. Id.

33 One observer has concluded that "[m]ost recently, network neutrality proponents have conceded the validity of access tiering and have simply argued for nondiscrimination within tiers." Christopher S. Yoo, What Can Antitrust Contribute to the Network Neutrality Debate?, 1 INT'L J. COMM. 493, 518 (2007). No evidence is cited in support of this conclusion, which seems too strong given the examples discussed in this section. Such a concession by network neutrality advocates, moreover, implies a rejection of the AT\&T merger condition, a condition that at least some network neutrality advocates applaud. The assertion also overlooks those advocates for whom a zero-price rule 


\section{Ends: "Anticompetitive Discrimination" and "Toll Booths"}

Commissioner Adelstein issued a statement explaining why he had insisted upon a network neutrality condition, and Commissioner Copps did the same. Adelstein decried the parties' incentives for "anti-competitive discrimination" 34 and understood the imposition of network neutrality as a way to prevent an access provider from acting upon that incentive. He chastised the Antitrust Division for what he viewed as its failure to act and argued that the Division's inactivity had made FCC action necessary. ${ }^{35}$ Put differently, he saw the Division's decisionmaking, and the FCC's, within an antitrust frame. The antitrust frame Adelstein apparently had in mind is a concern about exclusion-to return to the earlier example, that AT\&T, in exchange for payment, might favor YouTube over iFilm.

Copps took a different view. For Copps, the provision's value was to "ensure[]" that content providers and other Internet users "have the ability to reach the merged entities' millions of Internet users-without seeking the company's permission or paying it a toll." ${ }^{36}$ To worry about tolls is to worry about extraction, the use of a threat of exclusion to insist upon a share of content providers' profits. To be sure, Copps' statement did not rule out a concern about exclusion. A toll might be undesirable because the price is set so high that it deters a rival's entry. "Permission," if denied in equilibrium, amounts to exclusion. And Copps, like Adelstein, took the Antitrust Division to task for approving the merger unconditionally. ${ }^{37}$ But Copps did not limit his statement to the exclusion frame, nor did his reasoning rest upon the access provider's incentive to impair a particular content provider's competitive prospects.

Neither statement explained the need for a zero-price rule, rather than more limited regulation, or acknowledged the contrast between the two commissioners' views. These omissions are unfortunate, because the differences matter: the two theories have different economic effects, as explained in the next section, and are addressed to different degrees by existing law. Their conflation leads to confusion in assessing proposals for new regulation. For example, if Adelstein is right to focus upon exclusion, then why

does not go far enough. See, e.g., Susan P. Crawford, The Internet and the Project of Communications Law, 55 UCLA L. REV. 359, 403-04 (2007). For them, particular types of content should not be singled out for high-quality access, even if the access is provided for free. That outcome is a plausible reading of the AT\&T merger condition, which prohibits not only the sale of premium access but, equally, its "provi[sion]."

34 See In re AT\&T Inc. and BellSouth Corp. Application for Transfer of Control, 22 F.C.C.R. 5662,5837 (2007) (Adelstein, Comm'r, concurring) (arguing that the network neutrality condition was implemented to "address incentives for ant1-competitive discrimination").

$35 \quad I d$ at 5836.

36 Id. at 5831 (Copps, Comm'r, concurring). Commissioner Copps named as exemplars "[t]he next Drudge Report, Wikipedia, Craigslist, Instapundit, or Daily Kos." Id.

37 Id. at 5829. 
is the existing antitrust prohibition of exclusion, discussed in Part II, not a sufficient policy response? Why not seek instead a provision more closely tailored to exclusion concerns, rather than insist upon a zero-price rule, which, as we shall see, prohibits much more than exclusion? On the other hand, if extraction concerns justify a zero-price rule, as Copps suggests, can we ignore exclusion (and Adelstein's arguments) altogether? After all, a persuasive argument that rests upon extraction makes exclusion arguments unnecessary.

\section{B. The Potential Costs of Access Control}

Skeptics suggest that network neutrality regulation is a solution in search of a problem. ${ }^{38}$ The commissioners' statements indicate two distinct problems to which a zero-price rule might respond. Distinguishing them, and placing each on a more rigorous footing, is a necessary step toward evaluating each as a justification for a zero-price rule.

Both theories are premised upon the access provider's possession of significant market power. The access provider market is currently a duopoly. Consumers buy broadband access from AT\&T or another telephone company, or else from a cable company such as Comcast. ${ }^{39}$ Access provision has declining average costs, making it difficult for a second cable company or second local telephone company to enter. Switching costs are significant. In the future, wireless or other technology may provide a third source of provision, but for now, the access provider controls a bottleneck. Where there are multiple providers, moreover, the providers are not identical rivals. There is no guarantee that these alternatives (or others, such as wireless service) will coexist in long-term equipoise. A technology with clear superiority, if it emerges, might tip the market toward monopoly. ${ }^{40}$

38 For example, Representative Bobby Rush. See Anne Broache, Tech Manufacturers Rally Against Net Neutrality, CNET NEws.com, Sept. 19, 2006, http://www.news.com/2100-1028_36117241.html.

39 The FCC reports that nearly half of U.S. zip codes are served by either one or two ADSL or cable modem providers. FCC, HIGH-SPEED SERVICES FOR INTERNET ACCESS: STATUS AS OF JUNE 30, 2007 , at tbl.16 (2008), available at http://hraunfoss.fcc.gov/edocs_public/attachmatch/DOC280906A 1.pdf [hereinafter FCC DEPLOYMENT STUDY] (reporting one such provider in $24 \%$ of zip codes, and two such providers in $22 \%$ of zip codes). In addition, $10 \%$ of zip codes reported no DSL or cable modem providers. The fraction of consumers, as opposed to zip codes, served at most by a duopoly is higher, since a provider is counted for the entire zip code even if it serves only business customers and even if it serves only part of the territory (as usually will be the case for multiple cable companies, as their territones seldom overlap). See U.S. GEN. ACCOUNTING OFFICE, BROADBAND DePloyment Is EXTENSIVE Throughout THE UNITED STATES, BUt IT IS DifFICUlt to ASSESS THE

EXTENT OF DEPLOYMENT GAPS IN RURAL AREAS 16-17 (2006), available at http://www.gao.gov/new.items/d06426.pdf. Limiting consideration to DSL and cable modem is appropriate because these two technologies dominate the market. See FCC DEPLOYMENT STUDY, supra, at tbl.6. Mobile wireless has significant penetration (if included with DSL and cable modem provision, it would have a market share around $25 \%$ on a total-lines basis) but is not currently a close substitute for many users.

40 I thank Mark Lemley for pointing this out to me. 


\section{Exclusion and Reduced Competition}

An access provider with market power has, under certain circumstances, the incentive and ability to impair the competitive prospects of a content provider, in order to favor rival content in which the access provider has an economic interest. ${ }^{41}$ The reduced competition in content leads to higher content prices for consumers and allocative inefficiency when consumer purchases are deflected to less desirable substitutes, as well as a productive inefficiency when lower-cost content is kept from the market. ${ }^{42}$ The access provider profits from the reduced content competition either by owning the favored content or through a contractual relationship in which the content provider pays the access provider to exclude the rival content.

Under certain conditions, the access provider has no incentive to exclude in this way. ${ }^{43}$ It is a familiar result from platform economics that one impetus to exclude is missing when the application can be used only in conjunction with the platform-a video game that works only with a particular console, for example. The platform can then earn maximum profit from "captive" application users without taking over the application's business.

Internet content, however, has many nonplatform users, judged from the perspective of a particular access provider. The audience for iFilm's video service is not limited to AT\&T broadband customers. As a result, if AT\&T can induce iFilm's exit (or deter its entry in the first place), AT\&T might monopolize the content market through a corporate affiliate or contracting partner, and earn profit not only from captive AT\&T customers but also from noncaptive users of the content. ${ }^{44}$ For this strategy to work, the content

41 These practices are termed "vertical" because the contracting parties are at different stages in the chain of production or distribution, but the same arguments apply whenever the parties produce complements. For excellent modern accounts, see MICHAEL D. WHINSTON, LECTURES ON ANTITRUST ECONOMICS 133-97 (2006); Patrick Rey \& Jean Tirole, A Primer on Foreclosure, in 3 HANDBOOK of INDUSTRIAL ORgANIZATION 2145 (Mark Armstrong \& Rob Porter eds., 2007); Michael Riordan, Competitive Effects of Vertical Integration, in HANDBOOK OF ANTITRUST ECONOMICS (Paolo Buccirossi ed., forthcoming Apr. 2008).

42 If the platform owner is unable to make a binding contractual commitment to a single firm-because cheating is unobservable, perhaps, or the necessary contracts violate antitrust law-the platform may implement its commitment through vertical integration. If the vertical integration is inefficient, then exclusion entails a further social cost. See Oliver Hart \& Jean Tirole, Vertical Integration and Market Foreclosure, BROOKINGS PAPERS ON ECONOMIC ACTIVITY: MICROECONOMICS 205, 207-10 (1990); Rey \& Tirole, supra note 41, at 2158-62.

43 See Richard A. Posner, ANTitrust law 223-29 (2d ed. 2001); Aaron Director \& Edward H. Levi, Law and the Future: Trade Regulation, 51 Nw. U. L. REv. 281, $290-93$ (1956); Joseph Farrell \& Philip J. Weiser, Modularity, Vertical Integration, and Open Access Policies: Towards a Convergence of Antitrust and Regulation in the Internet Age, 17 HARV. J.L. \& TECH. 85, 100-19 (2003).

44 An early articulation is Michael D. Whinston, Tying, Foreclosure, and Exclusion, $80 \mathrm{AM}$. ECON. REv. 837 (1990). For a nontechnical treatment, see Dennis W. Carlton, A General Analysis of Exclusionary Conduct and Refusal to Deal: Why Aspen and Kodak Are Misguided, 68 ANTITRUST L.J. 659, 667-68 (2001). This is the classic "desert island" story, which Carlton attributes to Robert Gertner. Daniel Rubinfeld and Hal Singer applied this theory to the merger between Time Warner and America Online. See Daniel L. Rubinfeld \& Hal J. Singer, Open Access to Broadband Networks: A Case Study of 
provider must face economies of scale, such as a fixed entry cost or demandside network effects wherein one consumer's valuation of the content increases with the number of other users. Internet content provision often satisfies that assumption. The access provider must also be capable of disrupting, by means of exclusion, the content provider's ability to exploit scale. Whether access providers can deprive a content provider of scale is considered in Part II.

Commissioner Adelstein is far from alone in relying upon exclusion concerns to justify a zero-price rule. Google, for example, supports the rule to prevent "those last-mile activities that would discriminate against certain Internet applications or content with an anticompetitive intent. ${ }^{\text {"45 }}$ Scholars have hypothesized a negative effect on competition and explored at length the different mechanisms by which exclusion might occur. ${ }^{46}$ Legislative proposals that implement network neutrality have invoked the exclusion frame. ${ }^{47}$ When network neutrality proponents describe the historical antecedents of current policy proposals-for example, the famous exclusive contract between Western Union and the Associated Press-the examples reflect exclusion concerns. ${ }^{48}$ Network neutrality opponents understand proponents to be arguing that regulation is needed in order to address exclusion, ${ }^{49}$ prompting the response that exclusion is unlikely ${ }^{50}$ and best remedied by existing antitrust

the AOLTime Warner Merger, 16 BERKELEY TECH. L.J. 631 (2001) [hereinafter Rubinfeld \& Singer, Open Access]; Daniel L. Rubinfeld \& Hal J. Singer, Vertical Foreclosure in Broadband Access?, $49 \mathrm{~J}$. INDUS. ECON. 299 (2001) [hereinafter Rubinfeld \& Singer, Vertical Foreclosure].

45 Google Public Policy Blog, supra note 29.

46 See, e.g., Barbara van Schewick, Towards an Economic Framework for Network Neutrality Regulation, 5 J. ON TELECOMM. \& HIGH TECH. L. 329, 333 (2007) (arguing that the object of network neutrality is "to design rules that prevent network operators and ISPs from using their power over the transmission technology to negatively affect competition in complementary markets for applications, content and portals") (emphasis added).

47 For example, one bill favorably reported out of the House Judiciary Committee had as its announced purpose "to promote competition, to facilitate trade, and to ensure competitive and nondiscriminatory access to the Internet." Internet Freedom and Nondiscrimination Act of 2006, H.R. 5417,109 th Cong. $\S 2$ (2006) (statement of purpose). The accompanying report explained that the bill was designed to "preserv[e] an antitrust remedy for anticompetitive and discriminatory practices" by access providers. H.R. REP. No. 109-541, at 2 (2006); see also id. at 4 (emphasizing the similarity between this bill and earlier antitrust interventions in the telecommunications industry, particularly the breakup of the Bell System).

48 See, e.g., Tim Wu, Why Have a Telecommunications Law? Anti-Discrimination Norms in Communications, 5 J. ON TELECOMM. \& HIGH TECH. L. 15, 28-35 (2006) (reviewing Western Union's exclusive contract with the Associated Press, the Kingsbury Commitment, and Carterfone).

49 E.g., Owen, supra note 18, at 5; Bruce Owen \& Gregory Rosston, Local Broadband Access: Primum Non Nocere or Primum Processi? A Property Rights Approach, in NET NeUTRALITY OR NET NeUTERING: SHOULD BROADBAND INTERNET SER VICES BE Regulated? 163, 176 (Thomas M. Lenard \& Randolph J. May eds., 2006) ("The commercial demand for access regulation arises from a fear ... that [access providers] will themselves integrate vertically into various content, aggregation, or equipment businesses, and that this will be harmful to independent suppliers."); Yoo, supra note 33; see also Shelanski, supra note 7 , at 102 (characterizing network neutrality as a response to exclusion concerns).

50 See, e.g., J. Gregory Sidak, A Consumer-Welfare Approach to Network Neutrality Regulation of the Internet, 2 J. COMPETITION L. \& ECON. 349, 470-71 (2006). 
law. ${ }^{51}$ This focus is unsurprising, given the longstanding centrality of exclusion as a concern of telecommunications policy, ${ }^{52}$ and the focus upon exclusion in examining the merger of Time Warner and America Online, a notable precursor to the network neutrality debate. ${ }^{53}$

\section{Extraction and Reduced Innovation}

Even without equilibrium exclusion, an access provider can profit by extracting profits from the content provider. ${ }^{54}$ The access provider does not bother getting into the content business because it can capture the surplus produced by the content provider by virtue of its status as a bottleneck. For example, AT\&T might insist that YouTube and iFilm each pay AT\&T part of the content provider's profits in exchange for providing high-quality video transmission. Such access charges are a common practice in some industries. Video game console makers, for example, receive royalties from independent game developers. Credit card payment systems such as Mastercard and Visa charge merchants a transaction fee for use of the network. An extraction incentive is present even if the access provider has an affiliated, competing content provider, since each customer who uses the competing affiliated content, rather than the independent content, represents a foregone access charge. 55

Extraction entails a threat of exclusion, but the threat is not carried out in equilibrium; the threat is therefore not exclusionary conduct in the usual sense. The profitability of an extraction strategy, as implemented by an access provider or other platform, is premised upon a thriving set of independent applications. The activity is private taxation to raise revenue, rather than to deter. Exclusion relies upon disfavoring one content provider relative to another-the raising of a rival's costs. ${ }^{56}$ Concerns about extraction apply, by contrast, even if all content providers are affected equally and none is favored-where it is a complementor, rather than a rival, whose costs are being raised.

51 Hahn \& Litan, supra note 30, at 10-12.

52 See, e.g., Jonathan E. Nuechterlein \& Philip J. Weiser, Digital Crossroads: AMERICAN TELECOMMUNICATIONS POLICY IN THE INTERNET AGE 16-22 (2004).

53 See Rubinfeld \& Singer, Open Access, supra note 44; Rubinfeld \& Singer, Vertical Foreclosure, supra note 44.

54 Extraction is consistent with the "one monopoly profit" no-exclusion result-indeed, it is presumed in that account. See Jean Tirole, The Analysis of Tying Cases A Primer, COMPETITION POL'Y INT'L, Spring 2005, at 1; Whinston, supra note 44, pt. 3; see also Joseph Farrell \& Michael L. Katz, Innovation, Rent Extraction, and Integration in Systems Markets, 48 J. INDUS. ECON. 413 (2000); Farrell \& Weiser, supra note 43, at 104 (explaining that side payments are consistent with the "internalizing complementary efficiencies" baseline).

55 Tirole, supra note 54, at 6.

56 See Steven C. Salop \& David T. Scheffman, Raising Rivals' Costs, 73 AM. ECON. REV 267 (1983). 
Extraction is facilitated by effective price discrimination. That is, purchasers with relatively high willingness to pay and few effective substitutes for access provision are charged a higher price. Familiar examples include unrestricted airline fares and hardcover books. As discussed above, common carriers frequently implement price discrimination. Price discrimination increases the carrier's profits, thus providing an additional means to cover fixed costs. Price discrimination can also help to tune allocation and production decisions to better correspond to demand variations among consumers. ${ }^{57}$

On the simplest account, extraction simply shifts resources from the content provider to the access provider. Google and other content providers, of course, have reason to support a zero-price rule even if extraction raises merely a distributional issue without any consequence for efficiency. In addition, extraction has a dynamic efficiency consequence if it alters the investment decisions of content providers. ${ }^{58}$ As a theoretical matter, it may have no such consequence, given the access provider's incentive to increase surplus-which the access provider can then extract- by ensuring high-quality content. ${ }^{59}$ If there is a dynamic efficiency effect, it entails a tradeoff: reduced incentives for entry and investment by content providers, combined with increased incentives to invest in access provider infrastructure, via the contribution to fixed costs just mentioned. As a theoretical matter, it is not apparent which effect is larger.

Access providers have not defended any right to anticompetitive exclusion, but extraction is an explicit goal. AT\&T's CEO candidly explained that content providers "don't have any fiber out there. They don't have any wires. They don't have anything. They use my lines for free--and that's bull. For a Google or a Yahoo! or a Vonage or anybody to expect to use these pipes for free is nuts!"60 As Verizon's deputy general counsel explained his company's point of view: "The network builders are spending a fortune constructing and maintaining the networks that Google intends to ride on with nothing but cheap servers. It is enjoying a free lunch that should, by any rational account, be the lunch of the facilities providers."

57 For a thoughtful introduction to these issues, see Jeffrey K. MacKie-Mason \& Hal R. Varian, Pricing the Internet, in PUBLIC ACCESS TO THE INTERNET 269 (Brian Kahin \& James Keller eds., 1995); Hal R. Varian, Price Discrimination, in 1 HANDBOOK OF INDUSTRIAL ORgANIZATION 597 (Richard Schmalensee \& Robert Willig eds., 1989). Varian currently serves as chief economist at Google but has not joined Google's advocacy effort in favor of network neutrality regulation.

58 See, e.g, Gawer \& Henderson, supra note 5, at 5 (noting that platform incentives to squeeze complementors may undermine innovation incentives).

59 See infra Section III.D for further discussion.

60 Spencer E. Ante \& Roger O. Crockett, Rewired and Ready for Combat: SBC and Verizon Are Spending Billions to Stay Compettive in the Broadband Era, BUS. WK., Nov. 7, 2005, at 110 . See also Paul Taylor, AT\&T Chief Warns on Internet Costs, FIN. TiMES, Jan. 31, 2006, at 22 ("I think the content providers should be paying for use of the network. . . . They shouldn't get on [the network] and expect a free ride." (quoting AT\&T CEO Edward Whitacre)).

61 Arshad Mohammed, Verizon Executive Calls for End to Google's "Free Lunch," WASH. PosT, Feb. 7, 2006, at D1 (quoting Verizon deputy general counsel John Thorne). One spokesman put the issue this way: "Is the only potential payer going to be the end user, the customer, or are there other 
Extraction concerns-in particular, that extraction will reduce the profitability of and hence investment in independent content developmentmotivate many calls for network neutrality regulation. We saw one example already, in Commissioner Copps's statement about the AT\&T merger condition. $^{62}$ Some regulation proponents appear to focus upon extraction concerns and deemphasize anticompetitive exclusion. ${ }^{63}$ The same argument, and the reference to a "toll," have been emphasized by academics ${ }^{64}$ and interest groups. ${ }^{65}$ As Google's Vint Cerf, an Internet pioneer, has argued, network neutrality regulation ensures that "people with interesting ideas... [do] not have to leap over any kind of a hurdle to buy access to customers." member of the Federal Trade Commission has framed the network neutrality issue explicitly in extraction terms. ${ }^{67}$

\section{Additional Harms}

The two previous sections present a simple dichotomy. Exclusion is bad because it undermines competition. Extraction is troubling if it undermines innovation. This dichotomy, however, does not exhaust the harms of each

ways to finance infrastructure by asking content providers to pay as well?" Tom Abate, Speed Bumps on the Information Highway, S.F. CHRON., June 18, 2006, at Al (quoting Daniel Brenner, senior vice president for law and regulatory policy for the National Cable and Telecommunications Association).

62 See supra note 36 and accompanying text.

63 See, e.g., Network Neutrality: Hearing Before the S. Comm. on Commerce, Sci. and Transp., 109th Cong. 9 (2006) [hereinafter Lessig Testimony] (statement of Lawrence Lessig), available at http://commerce.senate.gov/pdf/lessig-020706.pdf (disclaiming reliance upon antitrust arguments); Brett M. Frischmann \& Barbara van Schewick, Network Neutrality and the Economics of an Information Superhighway: A Reply to Professor Yoo, 47 JURIMETRICS J. 383, 414 n.119 (2007) (explaining that network neutrality "goes beyond" antitrust reasoning by preserving high profits, and hence incentives, for independent content providers).

64 See, e.g., Lawrence Lessig, Congress Must Keep Broadband Competition Alive, FIN. TIMES, Oct. 19, 2006, at 17 [hereinafter Lessig, Congress] (identifying "internet toll booths" that “impos[e] a special tax"); Lawrence Lessig, I Blew It on Microsoft, WIRED, Jan. 2007, at 96 [hereinafter Lessig, $I$ Blew $I t$ ] ("Every dominant commercial competitor has the same incentive: to build a business that extracts all potential value from the pipes that company owns."); Lawrence Lessig \& Robert W. McChesney, No Tolls on the Internet, WASH. POST, June 8, 2006, at A23; see also Network Neutrality: Competition, Innovation, and Nondiscriminatory Access: Hearing Before the Telecom and Antitrust Task Force of the H. Comm. on the Judiciary, 109th Cong. 4 (2006) [hereinafter Wu Testimony] (statement of Tim Wu) (recognizing that nonneutrality amounts to a tax but likening its imposition to an illegal protection racket); $i d$. at 7 (describing the problem as "nothing more than a tax").

65 American Civil Liberties Union, ACLU \& Youth: Why We Need Net Neutrality Protections, http://www.aclu.org/freespeech/internet/27159res20061023.html (last visited Apr. 18, 2008) (offering "Expensive Downloads and [Podcasting]" as one of several reasons and noting that absent net neutrality, "network providers could charge you more to download ... videos or music, or to use services such as Rhapsody, YouTube, Napster, and iTunes... [and] tell you which download service you have to use, charging you a toll if you decide to use one of their competitors").

66 Abate, supra note 61, at A1.

67 See Jon Leibowitz, Comm'r, FTC, Concurring Statement Regarding Staff Report: Broadband Connectivity Competition Policy 2-3 (June 27, 2007), available at http://www.ftc.gov/ speeches/leibowitz/V070000statement.pdf (arguing that "expropriat[ion]" by access providers will harm long-run incentive to develop products). 
strategy. Exclusion, aside from its static consequences for competition, can undermine innovation in content. The anticipation of exclusion may discourage prospective entrants from developing new content. This consequence of exclusion, however, lacks a distinctive policy implication. If exclusion imposes a substantial static harm, then exclusion should be prohibited even if there is no dynamic inefficiency. Moreover, if the dynamic harms of extraction provide a strong general basis for zero-price regulation, it adds little to show that exclusion, when and if it occurs, also has a negative dynamic effect.

Extraction strategies can have static effects, aside from the dynamic effect on application innovation. Price discrimination, which is central to the operation of extraction, is typically executed imperfectly. A seller's information and contracting technologies are ordinarily not fine-grained enough to perfectly target the buyer's surplus. An application provider will engage in costly avoidance strategies and may pass along part of its increased expense to its consumers, perhaps in an inefficient fashion. ${ }^{68}$ In addition, the platform will expend real resources in order to improve its technology of price discrimination, including inefficient decisions about "vertical integration," the ownership of complementary businesses. These costs are difficult to evaluate and measure, which is one reason why the static inefficiency of imperfect extraction has not been a major focus of competition policy or a prominent argument for network neutrality proponents.

These effects complicate but do not erase the basic dichotomy. Exclusion raises distinctive concerns about static welfare losses, to which antitrust policy is primarily directed. Extraction raises concerns about dynamic welfare losses, particularly with respect to independent application development, and this is a preoccupation of innovation policy.

\section{The Consequences of Conflation}

Exclusion and extraction concerns raise different questions about the advisability of a zero-price rule. For extraction, three issues are most important. First, a zero-price rule might cause the access provider to effect extraction by other, less direct means. Second, a zero-price rule, to the extent it alters investment incentives, might not do so in a socially desirable fashion. Third, the access provider can "contract into" effective incentives for content development, despite its legal entitlement to extract. These questions are considered in Part III.

For exclusion, two issues arise. The first is superfluity: existing antitrust law prohibits some forms of exclusion. Provided that antitrust law as currently enforced successfully identifies and remedies exclusion, there is no need for

68 Joseph Farrell, Presentation at FTC Broadband Connectivity Competition Policy Workshop

155 (Feb. 13, 2007) (transcript available at http://www.ftc.gov/opp/workshops/broadband/ transcript_070213.pdf) (describing this problem). 
additional regulatory intervention. The second is overinclusion. Even if new regulation is necessary to prevent exclusion, it need not take the form of a zeroprice rule. A zero-price rule not only prevents an access provider from impairing a content provider's competitive prospects relative to a rival, but also prevents the charging of any access fee. That is, the rule prohibits both exclusion and extraction, a result that is difficult to justify unless extraction concerns are important.

Unfortunately, policy and academic discussions occur at a level of generality that subsumes exclusion and extraction arguments. Condemnations of access provider "discrimination" do not carefully distinguish practices that set different prices for different content types-a garden-variety extraction strategy of price discrimination ${ }^{69}$ - from practices that disfavor one content provider relative to its rival. Phrases that identify the desired end state, such as "innovation without permission," a uniform, zero price. In this respect, at least, the network neutrality debate presents nothing new, for similar confusion permeates analyses of common carriage as well. ${ }^{71}$

The resulting confusion has several bad consequences. Regulatory proponents justify a zero-price rule as a response to anticompetitive exclusion, without recognizing or justifying the rule's overinclusiveness relative to the exclusion concern. One of the more extreme consequences has been proposed legislation that would enshrine a zero-price rule as a substantive antitrust rule backed by private enforcement and treble damages. ${ }^{72}$ Meanwhile, skeptics aim their critiques at anticompetitive exclusion, thereby giving the extraction arguments short shrift.

\section{Reconsidering Exclusion}

This Part examines whether concerns about exclusion of content providers justify a zero-price rule. As a general matter, new regulation faces three formidable hurdles. First, there must be a plausible social harm to remedy. Second, existing law-here, antitrust law-must be an ineffective means of identifying and remedying the harm; otherwise, additional regulation is superfluous. Third, the regulation must effectively prevent the harmful conduct without also prohibiting too much harmless or desirable conduct, and without creating large new costs.

69 See Atkinson \& Weiser, supra note 7, at 50-51.

70 Letter from Jeff Bezos, CEO, Amazon.com, et al., to Senators Ted Stevens \& Daniel Inouye (Apr. 26, 2005), available at http://netcompetition.org/docs/pronetneut/leaders_042506.pdf.

71 As Bonbright explained in 1961, "Readers of the treatises and the case law on public utility and railroad rates will often come across bald statements to the effect that ... rate discrimination is unlawful.... [S] uch statements are grossly inaccurate. What the law forbids is merely 'undue' or 'unjust' discrimination." BONBRIGHT, supra note 19, at 370 .

72 See H.R. 5417, 109th Cong. \& 3 (2006) (adding a new section 28 to the Clayton Act). 
Section II.A considers the most famous modern example of anticompetitive exclusion, the U.S. government's antitrust case against Microsoft, as a source of analogies to the network neutrality context, in order to identify gaps in the existing prohibitions of antitrust that a zero-price rule might remedy. Sections II.B and II.C consider two possible gaps in antitrust coverage-call them the Vonage and Wikipedia gaps. The Vonage gap arises when an access provider, which already owns a legacy content business such as ordinary telephone service, excludes a competing content business. The Wikipedia gap arises when socially produced content competes with market production. Section II.B discusses why the Vonage gap does not justify zeroprice regulation. The Wikipedia gap presents a stronger argument for regulation, but, as explained in Section II.C, implementation of such regulation presents substantial practical difficulties.

\section{A. Identifying Gaps in Antitrust Law}

United States $v$. Microsoft offers a useful template to frame the incentives of access providers and content providers. ${ }^{73}$ In that case, the government alleged that Microsoft used its Windows operating system monopoly to impair the competitive prospects of Netscape's browser, in order to prevent the emergence of Netscape as a competing software platform. ${ }^{74}$ In order to exploit the analogy-which is inexact, to be sure ${ }^{75}$-we must first ask, who is Microsoft here? Is it the access provider or the content provider?

Consider, first, the access provider. An access provider could adopt a Microsoft strategy and preserve profits by forestalling competition in access provision. This scenario is a departure from the examples considered above. For example, AT\&T could secure an agreement with YouTube, providing that AT\&T customers receive exclusive access to YouTube content, thus shutting

73253 F.3d 34 (D.C. Cir. 2001) (en banc) (per curiam); cf. Lessig, I Blew It, supra note 64, at 96 (assessing the "Microsoft-like network-neutrality debate").

74 See 253 F.3d at 54-56 (discussing applications barrier to entry). For a technical account, see Dennis W. Carlton \& Michael Waldman, The Strategic Use of Tying to Preserve and Create Market Power in Evolving Industries, 33 RAND J. ECON. 194 (2002); for a nontechnical explanation, see Carlton, supra note 44 . This theory of exclusion is distinct from the one discussed in Part I, in which the platform excludes in order to harvest incremental profits from noncaptive application customers. This discussion focuses upon the conduct examıned in the D.C. Circuit's landmark 2001 decision. It omits discussion of the earlier per-processor license case, enforcement of the earlier consent decree, and later allegations involving the Media Player, server software, and desktop search integration into Windows Vista.

75 The particular mechanism considered in Microsoft, in which a complement today threatened to become a substitute in the future, is not directly applicable. But it may not be entirely irrelevant, if independent content providers threaten entry into the access provision business, as suggested by Google's recent interest in municipal Wi-Fi and 700-megahertz spectrum auctions. See Elinor Mills, Google Versus the Telecoms, CNET NEws.COM, Nov. 30, 2007, http://www.news.com/ Google-versus-the-telecoms/2100-1039_3-6220909.html (describing Google proposal, later abandoned, to offer municipal Wi-Fi in San Francisco, and plan to bid, ultimately unsuccessfully, in an FCC spectrum auction held in March 2008). 
out non-AT\&T customers within AT\&T's territory. The point would be to slow the entry or induce the exit of competing access providers, by depriving them of content valued by broadband consumers. ${ }^{76}$ Zero-price regulation-which aims to prevent differential treatment of content providers by an access provider, not differential treatment of access providers by a content providerdoes not address this problem at all.

Network neutrality discussions are not concerned with the Microsoft-like incentives of access providers, but rather with the Microsoft-like incentives of content providers. The worry is that a content provider, linked by contract or common ownership to an access provider, will compensate the access provider in exchange for the latter's exclusion of a competing content provider.

Focusing upon content provider incentives may seem an unfamiliar way to think about the problem, given the demonization of access providers that sometimes accompanies policy analyses of broadband regulation. The slippage occurs because in the most familiar scenarios of concern, the content business that benefits from exclusion is owned in common with the access business that does the excluding. For example, Time Warner produces content, such as CNN.com, in addition to providing broadband access. AT\&T, in addition to its Internet access business, provides ordinary telephone service-a content business, properly understood. The incentive of YouTube with respect to iFilm is analogous to CNN.com's incentive with respect to other news providers. So is AT\&T's incentive to preserve its legacy business from encroachment by Vonage and other companies deploying voice-over-Internet protocol (VoIP), which enables users to hold voice conversations by transmitting the information as packets, without paying for ordinary telephone service.

Despite the economic similarity, there is a crucial doctrinal difference between exclusion that occurs through contract, as in a hypothetical YouTubeAT\&T agreement to exclude iFilm, and exclusion accomplished through a refusal to deal-for example, a refusal by AT\&T to permit Vonage to reach AT\&T customers. Here we see a second use for the Microsoft analogy, besides the identification of troubling conduct, which is to identify the reach of existing antitrust prohibitions. Conduct that closely resembles the activity condemned in Microsoft is already subject to antitrust prohibition, and hence a poor candidate for new regulation. For exclusion accomplished by contract, such as the hypothetical YouTube-AT\&T agreement to exclude iFilm, a zero-price rule is

76 Put another way, a new entrant would be forced to secure an offering comparable to YouTube before entering and must now enter at both the platform and application layers. For a theoretical treatment of two-level entry, see Jay Pil Choi \& Christodoulos Stefanadis, Tying, Investment, and the Dynamic Leverage Theory, 32 RAND J. ECON. 52 (2001); see also Rubinfeld \& Singer, Open Access, supra note 44, at 657-61, which found anticompetitive exclusion of rival access providers to be an unlikely effect of the Time Warner-AOL merger. Some access providers do pay for premium content such as ESPN360, a web-based streaming video service that is apparently not offered exclusively. See Adam Thompson, ESPN Calls a Do-Over on Its Online-Video Site, WALl ST. J., Aug. 8, 2007, at B1 (reporting that Verizon and AT\&T have signed up for the service, while cable companies have declined). 
unnecessary. As the Microsoft case demonstrates, the substantive reach of antitrust law already extends to contracts that choke off the distribution options of a rival. ${ }^{77}$

The Microsoft comparison has a third payoff, which is to raise questions about the effectiveness of after-the-fact antitrust suits as a deterrent and remedy. Antitrust cases can take years to resolve, and in the meantime, an incumbent's control of the status quo can become entrenched. Microsoft is, perhaps, an apt example. Other cases, however, are less controversial demonstrations of the effectiveness of antitrust in coping with exclusion accomplished by contract. ${ }^{78}$

When an access provider acts in the interest of its content affiliate, as opposed to a contracting partner, the antitrust treatment is more complex. That circumstance is considered next.

\section{B. The Vonage Gap: Refusing to Deal with a Legacy Business Competitor}

Exclusion accomplished through a refusal to deal raises distinct issues. Although functionally similar to exclusion achieved pursuant to a contract, its legal treatment is different. The exclusion by refusal to deal is not covered by section 1 of the Sherman Act, which requires an agreement. ${ }^{79}$ That leaves section 2, which prohibits monopolization. ${ }^{80}$ But refusals to deal often fall outside the scope of section 2 , a lesson reinforced by a recent, controversial Supreme Court ruling. ${ }^{81}$

There is less to this apparent gap, however, than meets the eye. Fragmentation in the access provider market makes some refusals ineffective.

77 Such cases can proceed under either section 1 or section 2 of the Sherman Act. See, e.g., United States v. Visa, 344 F.3d 229 (2d Cir. 2003) (condemning, as violation of section 1, exclusionary agreements that prevented participating banks from issuing the credit cards of competing networks); Microsoft, 253 F.3d at 58-64 (condemning, as violation of section 2, contracts that prevented personal computer makers from distributing competing Netscape browser); see also United States v. Dentsply, 399 F.3d 181, 193 (3d Cir. 2005) (condemning, as violation of section 2, a sales condition imposed by a manufacturer that prevented buyers from purchasing products sold by competing manufacturers; condition was "as effective as those in written contracts"); $c f$. Lorain Joumal Co. v. United States, 342 U.S. 143 (1951) (condemning, as violation of section 2, a refusal to sell advertising space except on the condition that the customer not buy from a rival). For academic analyses, see Hahn \& Litan, supra note 30, at 10 (arguing that antitrust is sufficient to deal with "discriminat[ion] among unaffiliated content providers"); Robert W. Hahn \& Scott Wallsten, The Economics of Net Neutrality, ECONOMISTS' VOICE, June 2006, at 2, available at http://www.bepress.com/ev/vol3/iss6/art8 (similar).

78 For example, the Visa and Dentsply cases discussed supra at note 77. Moreover, ex ante regulation is hardly quick and painless in practice. A regulatory proceeding can also take years to reach a conclusion, and can itself entrench a nonoptimal industry arrangement. A thorough review of the debate over ex post and ex ante modes of regulation is beyond the scope of this Article. See supra note 7 for an introduction to the relevant literature.

79 See 15 U.S.C. $\S 1$ (2000). In this respect, the Vonage example resembles Theatre Enterprises, Inc. v. Paramount Film Distrib. Corp., 346 U.S. 537 (1954), in which each firm had an independent reason not to do business with the plaintiff, whatever choice its rivals made.

80 See 15 U.S.C. $\$ 2(2000)$.

81 Verizon Commc'ns Inc. v. Law Offices of Curtis V. Trinko, LLP, 540 U.S. 398 (2004). 
Moreover, where refusals do pose an anticompetitive threat, existing antitrust law may address that conduct-and even if not, a broad zero-price rule is an inappropriate means to address the conduct.

\section{Fragmentation of Access Provision}

Subsection I.B.1 introduced one theory of anticompetitive exclusion: that an access provider might monopolize a content market, in order to earn profit not only from its captive customers, but also noncaptive users of the content. A key condition for the success of that strategy is the access provider's ability through exclusion to undermine the content provider's achievement of effective scale-for example, by stealing so many customers that the application is unable to cover a large fixed cost or achieve sizable network effects among users.

That ability depends upon the importance of the access provider's captive customers to the success of the content provider. Even if a particular access provider has market power vis-à-vis its own consumers, it may be a quite unimportant source of customers for a content provider. The noncaptive customers-customers whose access is not controlled by the access providerprotect the content provider against exclusion by preserving the content provider's scale. ${ }^{82}$ The presence of such customers - the very prize that motivates exclusion, from an access provider's perspective-also makes exclusion more difficult to achieve.

Most content markets have a large number of noncaptive customers. That is true, even if the market for content is limited to U.S. broadband customers, since the largest U.S. access provider controls no more than a quarter of that market. ${ }^{83}$ For some content, dial-up service is sufficient, providing a content provider with an additional source of noncaptive customers, and hence scale. And some content reaches a global audience, in which case the threat to scale recedes further.

Some content providers enjoy a further advantage that reduces the exclusion threat. If the content is complementary to other content provided by the same firm-for example, Google's integrated search, e-mail, and office productivity offerings- the content provider will be less vulnerable to attempts by an access provider to induce its exit. As a general matter, then, a content

82 See Robert E. Litan \& Hal J. Singer, Unintended Consequences of Net Neutrality Regulation, 5 J. ON TELECOMM. \& HIGH TECH. L. 533, 555-58 (2007) (makıng a similar point).

83 As of the end of 2007 , cable had 33.5 million broadband subscribers, of which the main providers are Comcast (13.2 million), Time Warner (7.6 million), Cox (3.7 millon), Charter (2.7 million), and Cablevision (2.3 million). DSL had 28.5 million subscribers, of which the main providers are AT\&T (14.2 million), Verizon (8.2), Qwest (2.6 million), and Embarq (1.3 million). See Press Release, Leichtman Research Group, Over 8.5 Millon Added Broadband from Top Cable and Telephone Companies in 2007 (Mar. 3, 2008), available at http://www.leichtmanresearch.com/press/ 030308 release.html. On these figures, Comcast has a $21 \%$ share of U.S. broadband. 
provider is not very vulnerable to exclusion by an access provider that controls only a small part of the content provider's audience. That strategy can no more succeed than if a single computer manufacturer, such as Dell, had tried to shut down Netscape by refusing to carry the Netscape browser.

There is a second mechanism of exclusion by refusal to deal, however, to which the fragmentation critique does not apply. To see why, let us return to the "AT\&T versus Vonage" example. As already mentioned, AT\&T offers both broadband access and ordinary telephone service, a legacy content business that competes with independent VoIP providers such as Vonage. ${ }^{84}$ Allowing Vonage to reach AT\&T customers erodes the profitability of the legacy business unless AT\&T can implement an access charge that maintains existing profitability. ${ }^{85}$ Otherwise, the access provider's dominant strategy is exclusion.

Moreover, each access provider with a legacy business has the same incentive. Even if one access provider is too small to have much effect on application scale, the access providers' identical decisions, considered collectively, may have an exit-inducing effect. This is so, even if no access provider has any prospect of earning profits from noncaptive customers. The resulting exclusion-with accompanying static and dynamic harms-presents a significant problem for existing antitrust law, or else new regulation, to consider.

\section{Existing Antitrust Prohibitions}

It is a difficult question whether an access provider's refusal to deal with a VoIP provider triggers antitrust liability. Refusals to deal have long been controversial as a source of the anticompetitive action requirement of section $2,{ }^{86}$ even beyond the skepticism with which the judiciary views exclusion claims generally. ${ }^{87}$ The reluctance to impose liability has two bases. The first is that a refusal has welfare-increasing elements. For example, the prospect of profits from above-cost pricing is an inducement to innovative activity that

84 Major providers of broadband access also have VoIP businesses. See, e.g, Press Release, Comcast Corp., Comcast Reports 2007 Results and Outlook for 2008, at 3 (Feb. 14, 2008), available at http://biz.yahoo.com/prnews/080214/neth001.html (reporting 2.5 million "Comcast Digital Voice" subscribers, producing $\$ 1.8$ billion in revenue, offset by declining revenues from circuit-switched telephony).

85 In theory, AT\& $T$ could set an access fee equal to the profit lost from each customer that defects to Vonage, thereby causing Vonage to internalize the effect of its entry, and aligning the interests of the two firms.

86 See, e.g., United States v. Aluminum Co. of America, 148 F.2d 416 (2d Cir. 1945). One possible response is to attempt to impose liability only in a well-defined set of cases. For such a proposal, see Glen O. Robinson, On Refusing To Deal with Rivals, 87 CORNELL L. REV. 1177 (2002).

87 See, e.g., Schor v. Abbott Labs., 457 F.3d 608 (7th Cir. 2006) (Easterbrook, J.). 
mandated access undercuts. ${ }^{88}$ Refusal also preserves vertical integration, which internalizes demand externalities across complementary markets, thereby avoiding the so-called "double marginalization" problem. ${ }^{89}$ Refusal also avoids duplicative investments by content providers, a particularly relevant factor where the content provider offers a "me-too" product rather than an innovative improvement. $^{90}$

The second basis is a set of prudential concerns about the ability of a court to identify and accomplish procompetitive interventions in the marketplace. For example, it is difficult for an outside observer to discern what is going on, compared to contracted-for exclusion, when the relevant basis for comparison, the bottleneck's treatment of a corporate affiliate, is hidden from view within the firm. It is also difficult to identify natural limits upon the scope of liability, since almost any source of competitive advantage can be characterized as the bottleneck portion of an integrated firm and hence a candidate for courtmandated access. And it is difficult to identify the "right" regulated price, a question outside the competence of a generalist court. ${ }^{91}$

Beyond these policy bases for denying liability, a recent Supreme Court case, Verizon Communications Inc. v. Law Offices of Curtis V. Trinko, LLP, ${ }^{92}$ might seem to rule out liability entirely. There, plaintiff alleged that an incumbent local exchange carrier had refused to deal with a rival carrier, in violation of the carrier's interconnection obligation under the Telecommunications Act of 1996. One reading of that case, by no means the narrowest, is that refusals to deal by telecommunications providers are now beyond antitrust scrutiny. ${ }^{93}$

Despite these difficulties, a solid argument can be made that an access provider's refusal to deal with a VoIP provider does trigger antitrust liability by emphasizing the refusal's negative effect on competition (and, less convincingly, innovation ${ }^{94}$ ). Suppose, in what follows, that the welfare loss

88 Verizon Commc'ns Inc. v. Law Offices of Curtis V. Trinko, LLP, 540 U.S. 398, 407 (2004). This is the mainstream view. See, e.g., FTC STAFF REPORT, supra note 4, at 120 (quoting Trinko on this point with approval).

89 When multiple firms in complementary markets exercise market power independently, the aggregate distortion increases. For an early discussion of the point, see AUGUSTIN A. COURNOT, Researches INTO the Mathematical Principles of the THEORY OF Wealth 103 (Nathaniel T. Bacon trans., MacMillan 1927) (1838).

90 See N. Gregory Mankiw \& Michael D. Whinston, Free Entry and Social Inefficiency, 17 RAND J. ECON. 48 (1986) (demonstrating that free entry can be inefficient if entrants merely steal business from rivals); Patrick DeGraba, Why Lever into a Zero-Profit Industry: Tying, Foreclosure, and Exclusion, 5 J. ECON. \& MGMT. STRATEGY 433 (1996) (specifying conditions under which exclusion increases welfare by reducing wasteful duplication of fixed costs by independent producers).

91 See, e.g., Phillip Areeda, Essential Facilities: An Epithet in Need of Limiting Principles, 58 ANTITRUST L.J. 841, 841 (1990).

92540 U.S. $398(2004)$

93 A narrower reading, considered infra, limits the holding to situations where any competitive harm is already identified and remedied by the sector-specific regulatory regime.

94 The incumbents' own use of VolP suggests that VolP innovation might not depend upon granting access to independent VoIP providers. 
from reduced competition is larger than the welfare-increasing aspects of refusal-for if not, the basic premise for government intervention (whether by antitrust or new regulation) is lacking. In any event, the argument that a refusal has a welfare-increasing effect does not distinguish this conduct from an exclusionary contract, which (if permitted) also increases ex ante incentives, ${ }^{95}$ though the similar economic effects of exclusionary refusals and exclusionary contracts has been underappreciated by courts.

The remaining objections to antitrust liability can be overcome. Trinko does not stand in the way. Trinko and other cases have denied liability when the resource withheld by an incumbent is not generally available for sale: new product plans, as in Berkey Photo, ${ }^{96}$ or "unbundled network elements" not generally sold to consumers, as in Trinko. A VoIP provider such as Vonage, by contrast, seeks to take advantage of a facility that is made broadly available by the access provider. ${ }^{97}$ This distinction places a manageable limit on the scope of liability. Moreover, Trinko emphasized that effective sectoral regulation that addresses the conduct reduces the incremental value of antitrust intervention. ${ }^{98}$ Similarly effective regulation addressed to the conduct is absent here. In sum, Trinko does not bar antitrust liability for an access provider's refusal to deal with Vonage. ${ }^{99}$

If these arguments convince a court, then there is no role here for additional regulation. If not, and if (under our assumptions) there is a Vonage gap to fill, a zero-price rule is the wrong way to fill it. A zero-price rule is radically overinclusive relative to the Vonage gap. It prohibits not only parallel refusals to deal that are (possibly) outside the scope of antitrust, but also refusals that are unlikely to raise any competitive concern, exclusive contracts already prohibited by antitrust law, and extraction strategies that have nothing to do with competition.

Such overinclusion might conceivably be tolerated if no narrower rule were feasible. But in fact, a narrower rule is readily available. Restricting the rule's application to cases when the content provider seeks access from an access provider that owns a competing legacy business would focus the rule's scope. Prohibiting only discriminatory treatment for independent content, relative to affiliates, would likewise narrow the rule as to substance. To be sure, the narrower rule entails administrative complexity, in determining whether discriminatory treatment has occurred. But in this respect the seeming

95 Cf. Einer Elhauge, Defining Better Monopolization Standards, 56 STAN. L. REV. 253, 30105 (2003) (noting pervasiveness of tradeoff between innovation and competition).

96 Berkey Photo, Inc. v. Eastman Kodak Co., 603 F.2d 263, 274, 276, 287 (2d Cir. 1979).

97 See Aspen Skiing Co. v. Aspen Highlands Skiing Corp., 472 U.S. 585 (1985) (imposing liability where defendant denied access to product generally available for sale).

98 Verizon Commc'ns Inc. v. Law Offices of Curtis V. Trinko, LLP, 540 U.S. 398, 411-15 (2004).

99 An alternative strategy is to characterize the conduct as tying or predation. See Robinson, supra note 86, at 1178 (arguing that opportunities to recharacterize are pervasive). 
comparative simplicity of the zero-price rule-that it does not require detailed price regulation ${ }^{100}$-is misleading. If an access provider with a content affiliate reduces quality without raising prices, that form of discrimination will be difficult to observe, much less to establish in a judicial or administrative proceeding. A zero-price rule necessitates an administratively difficult inquiry into the quality of access granted. ${ }^{101}$

In short, even if (as we have assumed) a parallel refusal to deal creates a net social harm, and even if antitrust liability does not extend to that case, a zero-price rule is difficult to understand as a response to the resulting Vonage gap.

\section{The Wikipedia Gap: Exclusion of Social Production}

The Vonage example raises a general issue. Where an access provider is able to collect profits from one content provider but not its rival, ${ }^{102}$ the access provider has an incentive to exclude the latter content provider. Social production presents a second situation where an inability to extract creates an incentive to exclude, and in which parallel action by access providers can have a large aggregate effect. As explained in this section, social production has distinctive features that make it unusually valuable, but also unusually vulnerable, to a particular form of exclusion. That mechanism of exclusion is not subject to the prohibitions of antitrust law, moreover, presenting a relatively stronger argument for regulation.

\section{Distinctive Features of Social Production}

Up to now, we have assumed that content is provided by an ordinary market actor, such as YouTube, Vonage, or the New York Times. But socially produced content is a distinctive source of Internet content. Social production, as I use the term, entails collaboration by a large number of decentralized, unpaid individuals, who derive utility from producing despite —or because of the lack of direct financial incentive. The major conditions for success are that

100 A zero-price rule sidesteps the concern raised by Owen, supra note 18 , at 2 , that "[n]et neutrality policies could only be implemented through detailed price regulation."

101 A more aggressive solution to the incentive to favor affiliated producers is line of business restrictions. The most famous example is the AT\&T government consent decree. United States v. AT\&T, 552 F. Supp. 131, 224 (D.D.C. 1982), aff $d$ sub nom. Maryland v. United States, 460 U.S. 1001 (1983). This solution has drawbacks of its own, including the limits it imposes upon efficient vertical integration. For a summary of this debate, compare Mark A. Lemley \& Lawrence Lessig, The End of End-to-End: Preserving the Architecture of the Internet in the Broadband Era, 48 UCLA L. REV. 925, 940-46 (2001) (advocating separation in the context of broadband carriers and Internet service providers), with Farrell \& Weiser, supra note 43, at 100-05 (notıng efficiency of vertical integration and incentives to maximize overall value), and James B. Speta, A Vision of Internet Openness by Government Fiat, 96 NW. U. L. REV. 1553, 1565-66 (2002) (reviewing LAWRENCE LESSIG, THE FUTURE OF IDEAS: THE FATE OF THE COMMONS IN A CONNECTED WORLD (2001)) (similar).

102 Or capture the surplus by raising the access price to consumers. See infra Section III.A. 
the inputs to production are decentralized (or else public goods) and that the overall project can be subdivided effectively. ${ }^{103}$ Examples include the collaborative encyclopedia Wikipedia and distributed computing projects such as Folding@home. ${ }^{104}$

Social production has a distinctive virtue and, in some circumstances, a distinctive vulnerability. The virtue is that social production can be more efficient than market production, in part because it avoids transaction costs in the sharing of excess capacity (for example, computer processing cycles and leisure hours). ${ }^{105}$ The vulnerability arises when social production competes with market-produced Internet content, and exclusion by a broadband access provider is feasible. Wikipedia, for example, competes with Encyclopedia Britannica and other for-profit encyclopedias. (The present analysis thus excludes many other forms of "social" collaboration, such as a book club or a family, that do not face that exclusion threat.)

The distinct vulnerability is that a social producer is less able to pay an access fee. The degree of disability varies. Some may be able to raise funds, by charging consumers or accepting advertising. (These and other sources of protection are considered below in Subsection II.C.3.) But fundraising may be impractical due to the transaction costs of raising small amounts of money from each of many users, and the risk that collecting money or permitting advertising will disrupt the nonfinancial esprit de corps on which the success of social production, in some cases, may rest. ${ }^{106}$ If so, the social producer may be vulnerable to the mechanism of exclusion considered next.

\section{Mechanism of Exclusion}

Social production alters the competitive dynamic between content providers and access providers. An access provider has an incentive to earn profits from a content provider by offering premium access in exchange for a fee. To fix ideas, suppose Wikipedia and Encyclopedia Britannica offer competing encyclopedias to consumers. An access provider offers faster access at a premium price, and makes this offer available to all interested content providers. Customers prefer faster access, so Encyclopedia Britannica pays the fee. Wikipedia, though offered the same terms, is unable to pay, and loses some customers as a result. Each access provider has the same incentive; for each, it

103 For a fuller account, see BENKLER, supra note 6, at 99-106.

104 See http://folding.stanford edu (last visited Apr. 18, 2008). The project uses the spare computing power of distributed users to solve computation-intensive problems related to protein folding, a key step in understanding how misfolded proteins cause disease.

105 BENKLER, supra note 6, at 106-16; see also Josh Lerner \& Jean Tirole, Some Simple Economics of Open Source, 50 J. INDUS. ECON. 197, 212-20 (2002) (discussing career concerns and ego gratification as incentives for social production).

106 Cf. Uri Gneezy \& Aldo Rustichıni, A Fine Is a Price, 29 J. Legal Stud. 1 (2000) (describing how introduction of financial penalties can alter altruistic behavior). 
is a dominant strategy to offer the premium service and for Encyclopedia Britannica to accept.

The aggregate effect of the premium service contracts is to deprive Wikipedia of scale. If fewer consumers look to Wikipedia for answers, then likely fewer will contribute, reducing its quality. More generally, social production will suffer where the content's value enjoys increasing returns to scale. If the provider has significant fixed costs, otherwise covered by charging consumers or accepting advertising (for those social producers that can raise limited funds), reduced access to consumers may undermine its ability to cover those costs.

The exclusionary effect of the premium access contracts can reduce welfare. If social production is excluded or suppressed, society loses the productive advantages that can accompany social production. Nevertheless, antitrust law does not prohibit this welfare-reducing transaction. Each access provider here has an incentive to exclude without agreement among the providers. The incentive does not necessarily depend upon a strategic motivation to impede the socially produced content provider or deprive it of scale. Here, an antitrust enforcer would focus upon the increased consumer satisfaction from faster speeds, and the fact that Encyclopedia Britannica and the access provider would make this agreement, whatever the effect upon Wikipedia. The rationality of this conduct, even without considering the negative effect on Wikipedia, differentiates this situation from a payment by Encyclopedia Britannica made only to cause the access provider to block access to Wikipedia, a payment which would violate antitrust law. ${ }^{107}$

\section{Limited Feasibility of Regulation}

The welfare-reducing nature of the transaction just described, combined with an absence of antitrust enforcement, implies a gap in existing law, and hence a potential role for a narrowly focused zero-price rule. Unlike the Vonage gap, moreover, the Wikipedia gap cannot be filled with a weaker rule that merely requires an access provider to make any offer generally available to rivals. It is useless to insist that an access provider make Wikipedia an offer it

107 The vulnerability of social production in its competition with market production is a significant challenge to its viability as a mode of production. See Lior Jacob Strahilevitz, Wealth Without Markets?, 116 YALE L.J. 1472, 1493-1504 (2007) (reviewing YOCHAI BENKLER, THE WEALTH OF NETWORKS: HOW SOCIAL PRODUCTION TRANSFORMS MARKETS AND FREEDOM (2006)); $c f$. BENKLER, supra note 6, at 383-459 (describing a wide variety of policy challenges to social production). Strahilevitz considers several ways in which Encyclopedia Britannica might pose a challenge to Wikipedia, including the insertion of deliberate errors, Strahilevitz, supra, at 1497, and (more generally) the purchase of excess capacity on which social production relies, id. at 1499. By contrast, the distinct mechanism considered here need not rely upon a deliberate strategy of exclusion by the market producer. 
cannot accept. A rule that merely policed the offers made would fail to prevent the social harm. ${ }^{108}$

A zero-price rule, implemented where social production competes with market production, amounts to a tailored subsidy for social production. The "subsidy" label is not itself troubling; many protective regulations, including antitrust law, provide effective subsidies to their beneficiaries. Nor is a narrow zero-price rule merely a subsidy to support amateurs, vulnerable to Coase's acid quip that "an amateur is someone who does not pay for the things he uses." 109 The underlying premise is that social production brings distinctive economic benefits, described above, that merit protection if regulation can be accomplished at acceptable cost.

Moreover, much social production has no plausible claim to protection. First, new regulation has no place where the social producer can collect substantial fees from users. In some circumstances, fee collection will be feasible; social producers can and do pay some bills. ${ }^{110}$ Second, new regulation has no place where the access provider is able to collect fees from users, for if so, exclusion is no longer a more profitable strategy for the access provider. ${ }^{11}$

Third, new regulation has no place where the social producer has powerful market complementors. Where a market producer benefits from the success of social production, it has an interest in preserving the success of the social producer. It will assist in the implementation of counterstrategies that undermine exclusion. ${ }^{112}$ For example, IBM has an incentive to protect Linux as a complement to certain IBM businesses. Similarly, open-source programmers who write code to make the online community Second Life more accessible to disabled people are in little danger, given the interest of Linden Lab, Second Life's owner, in preserving their success. ${ }^{113}$

108 Nor would the line-of-business restriction considered in Section II.B help. A still narrower rule, however, is possible: to prohibit charges only as to the socially produced content, while permitting access charges to the rival market-produced content. That narrower rule would increase the effective subsidy to socially produced content at the expense of market-produced content.

109 See R. H. Coase, The Federal Communications Commission, 2 J. L. \& Econ. 1, 37 (1959). The subject was a then-novel proposal to create property rights in electromagnetic spectrum, and Dallas Smythe, a former chief economist of the FCC, had presented a series of objections, such as the displacement of current users, including radio amateurs, "which by definition could hardly be expected to pay for frequency use." Dallas W. Smythe, Facing Facts About the Broadcast Business, 20 U. CHI. L. REV. 96, 99 (1952). Coase's quip was part of a critique of Smythe's views.

110 See, e.g., What We Need the Money For, http://wikimediafoundation.org/wiki/ what_we_need_the_money_for (last visited Apr. 18, 2008) (describing uses of donations to Wikipedia); Wikimedia Fundraising, http://fundraising.wikimedia.org (last visited Apr. 18, 2008) (listing donations).

111 User fees, whether levied by the social producer or the access provider, are more feasible where the value to each user is relatively large and either does not vary too much across consumers or price discrimination is sufficiently effective to capture the variation.

$112 C f$. Frank H. Easterbrook, Predatory Strategies and Counterstrategies, 48 U. CHI. L. REV. $263,284-88$ (1981) (describing a variety of strategic responses to an incumbent's predation).

113 See Linden Lab, Open Source, http://secondlifegrid.net/programs/open_source (last visited Apr. 18, 2008) (noting availability of source code for Second Life Viewer). 
These three conditions, taken together, cabin the scope of protection to a substantial degree. In those remaining instances where social production faces a market rival, an access provider could be forbidden to charge for premium service where such a charge would create a significant risk of exclusion due to the social producer's inability to pay. It is worth asking, of course, whether new regulation, thus limited, is worth having. An affirmative answer requires confidence in several propositions: that social production offers unique value, that exclusion will cause that value to dissipate rather than shift to similarly valuable but less vulnerable social production projects, that worthy and unworthy claimants to the subsidy can be distinguished, ${ }^{114}$ and that a subsidy borne in the first instance by access providers is more efficient than one drawn from general taxation. And there remain the usual difficult questions of implementing a zero-price rule identified in other critiques of network neutrality regulation, including the risk of entrenching the technological status quo, the vulnerability of new regulation to capture, and the loss of transparency that accompanies use of a disguised subsidy through regulation rather than a direct payment. These difficulties are general to all applications of zero-price rules, and do not alter the result that social production provides a relatively promising focus for proponents of zero-price rules, compared to marketproduced content.

The foregoing analysis demonstrates that Commissioner Adelstein and Google are wrong to look to a zero-price rule as a necessary means to protect content providers generally from exclusion. Regulatory proponents have two options, which are not mutually exclusive. They can narrow their advocacy to protection of socially produced content-an underexplored option-or rely upon a second economic argument for zero-price regulation, that such rules are needed as a response to extraction, to which we now turn.

\section{Reconsidering Extraction}

Extraction concerns are at the heart of modern advocacy of zero-price regulation. ${ }^{15}$ As explained in Part $\mathrm{I}$, the central extraction concern is that when an access provider charges a content provider for access, the content provider's profits fall. The reduction in prospective profits reduces a content provider's incentive to innovate and hence the amount of innovation.

Compared to exclusion, extraction is a more promising ground for regulation, for two reasons. First, antitrust law does not already prohibit extraction. Regulating extraction is the realm of industrial policy, not competition policy. Second, a zero-price rule is better tailored to extraction

114 As a theoretical matter, if protection of social production were sufficiently important, overinclusion might be tolerated as a second-best measure.

115 See, e.g., Frischmann \& van Schewick, supra note 63, at 414 n.119 ("Proposals for network neutrality are driven by concerns about a reduction in application-level innovation."); id. at 416 n. 128 (similar). 
concerns than it is to exclusion concerns. The source of the posited problem is the transfer of profits from a content provider to an access provider; the proposed solution is to prohibit transfer. A weaker rule that permits extraction, provided only that the extraction is conducted in an evenhanded manner, does not solve that problem.

As noted in Part I, the extraction argument attracts an immediate response: that not only content innovation but also infrastructure innovation must be taken into account, and that subsidizing content development necessarily comes at the expense of network development. Optimal compensation to the access provider and the content provider is a joint innovation problem. In general, the benefit from an application used in conjunction with a platform - whether a new video game compatible with a console or a new search engine used by broadband consumers-is made possible by two distinct investments. One is the investment made to design and develop the application. The platform owner makes an investment, too, in the infrastructure necessary to deliver or enable the complementary application. These two actions jointly produce incremental value, a point not lost on industry insiders in the network neutrality context. ${ }^{116}$

With a single innovator, there is a benchmark "internalization" solution, in which an inventor is paid an amount equal to the social value she creates. ${ }^{117}$ An amount less than full internalization will also induce the invention, provided that it covers the inventor's costs, including her opportunity cost in developing the invention. ${ }^{118}$ The internalization solution fails under joint innovation. When two inventors are each but-for causes of an increase in value, paying each of them an amount equal to the increase is problematic for two reasons. First, if payments from users privately fund the innovation, there is not enough compensation to go around. Second, that solution, even if feasible, would inefficiently induce innovation even where it is not cost justified. ${ }^{119}$ Joint innovation is a classic, notoriously difficult problem in the regulation of innovation. How best to provide incentives to multiple innovators has been a

116 Verizon CEO Ivan Seidenberg articulated a similar sentiment: "Those guys [Google and Microsoft] gotta use a network. But it's also incredible when you see the innovation that a Google, a Microsoft or an AOL can create. In the long run, Google won't work without us, and we won't work without them." Paul Kapustka, Verizon Says Google, Microsoft Should Pay for Internet Apps, INFORMATIONWEEK, Jan. 5, 2006, http://www.informationweek.com/news/showArticle.jhtml? articleID $=175801854$.

117 Michael Kremer, Patent Buyouts: A Mechanism for Encouraging Innovation, 113 Q.J. ECON. 1137 (1998); Steven Shavell \& Tanguy van Ypersele, Rewards Versus Intellectual Property Rights, 44 J.L. \& ECON. 525 (2001).

118 For an argument emphasizing this point, see Brett M. Frischmann \& Mark A. Lemley, Spillovers, 107 COLUM. L. REV. 257, 276-79 (2007).

119 Suppose that two jointly necessary innovations, which cost $a$ and $b$ to develop, produce social value $v$. Inducing the innovation is efficient provided $a+b<v$. But the compensation structure discussed in the text induces innovation whenever $a<v$ and $b<v$, even if $a+b>v$. 
particular preoccupation of patent scholarship. No consensus answer has emerged. ${ }^{120}$

Four problems, each underappreciated in the existing literature, undercut the extraction-based argument for a zero-price rule. First, zero-price rules prohibit direct extraction but permit more costly indirect extraction, causing implementation of the rule to unravel in practice. Second, nonfinancial motivations to create Internet content reduce the negative effect of extraction on content development. Third, extraction may be a principal component of a plan to increase consumer "spillovers" by subsidizing consumer broadband adoption. Fourth, it has not been established empirically that independent content will be starved for investment without a shift in the regulatory entitlement.

\section{A. The Indirect Extraction Problem}

A zero-price rule is asymmetric. It prohibits an access provider from charging a content provider to send information to consumers, but permits charging the consumer to receive that information. The AT\&T merger condition, for example, prohibits discrimination among content providers, but permits it for consumers desiring different quality of service for a particular kind of data. ${ }^{121}$ Network neutrality proponents frequently approve discrimination among consumers. ${ }^{122}$

The appeal of asymmetric regulation is easy to see. Proponents of regulation fear that an access provider will misbehave toward content providers. Regulating the interaction between the two is the most direct response. Moreover, as regulation proponents concede, price discrimination is a useful tool for fixed cost recovery. ${ }^{123}$ If the access provider is to take advantage of this tool, yet not discriminate among content providers, it must be able to price discriminate among consumers.

The problem with this view is that asymmetric regulation can unravel. As a general matter, a platform is not limited to access fees as a means to extract profits from an application. It can instead raise its price to consumers to a level

120 Compare SuZANNE SCOTCHMER, INNOVATION AND INCENTIVES 135-42 (2004) (describing circumstances under which upstream inventor is most important to protect), with John $\mathrm{H}$. Barton, Patents and Antitrust: A Rethinking in Light of Patent Breadth and Sequential Innovation, 65 ANTITRUST L.J. 449, 453-55 (1997) (arguing that downstream inventor is proper focus of protection).

121 The terms of AT\&T's commitment apply to discriminatory provision or sales to a content provider, but not to a consumer.

122 See Lessig Testimony, supra note 63, at 2 (endorsing consumer tiering as means to fund infrastructure development); Lessig AEI Presentation, supra note 15, at 24:05 (same); see also Atkinson \& Weiser, supra note 7, at 50 (concluding that "all parties in this debate agree [that] broadband operators should be able to charge consumers for different levels of broadband service"); Yoo, supra note 33, at 517 (concluding that network neutrality proponents have "conceded the validity of consumer-side tiering"). But see Frischmann \& Lemley, supra note 118, at 297-98 (suggesting that consumer price discrimination is impermissible).

123 See, e.g., Lessig Testimony, supra note 63, at 9. 
that captures consumers' incremental gains from use of the application. The more the platform charges, the less surplus is left over for the application to capture as profit. ${ }^{124}$ In the most extreme version, the platform captures all of the surplus created by the application, forcing the application to sell at cost. ${ }^{125}$

A platform's choice of strategy depends upon the web of ongoing financial relationships among the platform, application, and consumer. For example, where the platform lacks an ongoing financial relationship with the consumer, an access charge levied upon the application provider is easier to implement-a game console maker can more readily charge game makers a royalty on each game sold, rather than charge consumers for each game purchased. Setting a high consumer access price is an attractive alternative where the platform has an ongoing financial relationship with the consumer, ${ }^{126}$ and the consumer has a relationship with the application. ${ }^{127}$

A zero-price rule that bans direct extraction through an access charge leaves open indirect extraction through a higher consumer access price, and a rational access provider will take advantage of this loophole. An access provider might offer customers, for a fee, higher-quality access to a particular type of content, such as video streaming or search results, in the expectation that content providers will compensate the consumer for the higher price. To continue the taxation analogy, it is as though policymakers had implemented a value-added tax and decided to shift collection of the tax from sellers to buyers. That shift does not change the incidence of the tax.

Compensation can take several forms. Content providers already compensate consumers directly to use their services. Some firms have paid customers for the privilege of connecting them to advertisers. ${ }^{128}$ Microsoft has announced a plan to pay companies to use its search product. ${ }^{129}$ Some

124 Rey \& Tirole, supra note 41, at 2186; J.A. Ordover et al., Nonprice Anticompetitive Behavior by Dominant Firms Toward the Producers of Complementary Products, in ANTITRUST AND REGULATION: ESSAYS IN MEMORY OF JOHN J. MCGOWAN 115, 116-17 (Franklin M. Fisher ed., 1985).

125 Rey \& Tirole, supra note 41 , at 2186 (considering a model in which the platform owner sets the price first, capturing surplus and forcing the application to sell at cost); Farrell \& Katz, supra note 54 , at $414 \&$ n.4 (similar).

126 In practice, the console maker may enjoy a continuing relationship with the consumer through the sale of warranties, downloadable legacy games, and access to online gaming networks.

127 In effect, a "two-sided" market becomes "one-sided." For a technical exposition, see Rochet \& Tirole, supra note 5, at 648 (one-sidedness exists where the volume of transactions depends only upon the price level, not the price structure). See infra Section III.C for further discussion of twosided markets.

128 See, e.g., Ariana Eunjung Cha \& Leslie Walker, A Pyramid Marketing Ploy Clicks, WASH. Post, Dec. 8, 1999, at A1 ("AllAdvantage and dozens of other companies are rushing to build big audiences by handing out cash to people willing to let advertisers track their Web surfing and send them ads tailored to their habits."). This strategy, however, has not proved particularly successful. See Posting of Duncan Riley to TechCrunch, http://www.techcrunch.com/2007/12/10/agloco-doesnt-pay-tosurf-joins-deadpool (Dec. 10, 2007) (describing demise of a successor to AllAdvantage).

129 See Thomas Claburn, Microsoft Pays Enterprise Customers to Adopt Windows Live Search, INFORMATIONWEEK, Mar. 16, 2007, http://www.informationweek.com/news/ 
compensation is less explicit, as with advertising exposure that is traded for free content. ${ }^{130}$ Compensation could also take the form of a decrease in the amount consumers would otherwise pay the content provider for a particular service.

The strategy applies not only to content providers that earn profits by charging consumers, but also to content providers that profit by charging third parties such as advertisers or by reducing costs through online rather than faceto-face transactions. The access provider can capture these gains, too, through careful consumer pricing. ${ }^{131}$ For example, suppose that a consumer receives a benefit of 40 from using a particular type of content, plus an additional benefit of 60 from access to all other types of content. Each provider of the particular type of content receives no revenue directly from consumers but earns 50 from advertising. A zero-price rule prevents the access provider from charging the content provider directly for access.

If the access provider sets a price to consumers of 100 , it captures the consumer's gain but not the content provider's profits. But the access provider can do better by charging a price of 150 . This is more than the consumer's benefit of 100, and so the consumer will not purchase access (and thereby access the content) unless compensated 50 to do so. But the content provider will have the necessary incentive to pay the consumer 50 -for without the consumer, it cannot reap the benefit of advertisement-in order to make the overall transaction worthwhile. This is an extreme example, in which the entire benefit is handed to the access provider, but the point is general. In this way, indirect extraction induces the content provider to offer consumers a negative price, as in the Microsoft example.

Nor does this technique exhaust the instruments of indirect extraction. An access provider, prohibited from charging an access fee, could invest in the development of a competing application. The goal is not to reduce independent content development-though this may be a byproduct-but rather to put downward pressure on the price charged, thereby increasing the consumer surplus that the access provider can capture. ${ }^{132}$

Indirect extraction undermines the effectiveness of a zero-price rule as an instrument for preventing direct extraction. If an access provider captures profits by charging consumers based upon the content used (in anticipation of content provider reimbursement of the consumer), rather than charging the content provider directly, there will be a reduction in content provider profits,

showArticle.jhtml?articleID=198001615 (describıng plan to pay businesses on a per-PC basis for use of Microsoft's Live Search product).

130 The compensation is particularly clear when the exchange is sequential rather than simultaneous, as with Salon's Ultramercials. Stefanie Olsen, Salon: Watch Ad, Read Articles For Free, CNET NEwS.COM, Nov. 20, 2002, available at http://www.news.com/2100-1023-966664.html.

$131 C f$. van Schewick, supra note 46 , at 342-45 (concluding that content provider profits earned from advertising can be extracted by an access provider only through vertical integration).

132 See, e.g., Ordover et al., supra note 124, at 116-17. 
the very effect that a zero-price rule aims to prevent. Moreover, because indirect extraction has a tendency to restore the status quo, critics of zero-price rules may not see their fears materialize. ${ }^{133}$

At the same time, the access provider's resort to indirect extraction creates several new sources of social cost. Those costs include the implementation of the indirect extraction scheme and countermeasures by consumers and content providers to insulate themselves from indirect extraction. In tax terms, shifting the collection from sellers to buyers can alter the cost of collection, independent of the tax's incidence. As a matter of theory, it is uncertain whether these costs are greater than the costs of implementing a direct extraction scheme and of countermeasures employed by content providers to insulate themselves from direct extraction.

Indirection does not undermine zero-price regulation aimed at exclusion, or at least not to the same extent. Indirect exclusion, to be effective, requires a narrowly focused deal between an access provider and a consumer that favors one content provider over its rival. But that level of specificity will be difficult to implement. For one thing, an explicit contract implementing that discriminatory deal would raise antitrust concerns, for the reasons discussed in Part II. Moreover, if an access provider is limited, as a legal or practical matter, to consumer pricing that varies with the type of content and intensity of use, but not the particular content provider, then indirect exclusion will be difficult to implement.

\section{B. Nonfinancial Incentives to Develop Content}

A tax on innovative content burdens both startups and established firms. Some advocates worry that this burden will disproportionately fall upon startups. ${ }^{134}$ But this is not a necessary outcome. First, it is not clear what constitutes a disproportionate burden. Extraction, from the content provider's perspective, resembles an electrical bill or building rent, and we would not normally think of these latter categories as posing an unusual, disproportionate burden upon a startup content provider that ought to be remedied by requiring the service provider to provide a discount or rent abatement.

Moreover, the relative burden depends upon the fine detail of the access charge-a lump sum versus a percentage of profits, or a graduated scale

133 For a representative example of such fears, see Sidak, supra note 50, at 351-52 (arguing that network neutrality regulation will deny access to consumers with low willingness to pay).

134 For example, Lessig writes:

[I]t will be the new innovators who bear the burden of these taxes most heavily. The point is obvious when you think about the history of YouTube. Had network owners been charging an access premium, investors in an upstart like YouTube would have had good reason to think twice. All taxes are a barrier, but this tax would be a particularly high barrier to innovation. It would hinder newcomers such as YouTube by favouring established companies such as Google and Yahoo.

Lessig, Congress, supra note 64 . 
indexed to use of the network. An access provider has a strong incentive to maximize the value of complementary applications. ${ }^{135}$ An access provider has an incentive to "soak the rich," whose investments are already sunk, rather than fledgling firms that are a source of future profits-or a source of competition to other content providers, ultimately making more surplus available for capture by the access provider.

That prospect might nevertheless have some chilling effect on a fledgling content provider that makes decisions based upon the probability of future great wealth. This concern, however, is undermined by a particular feature of content development: nonfinancial incentives to create content. Much of the celebrated explosion of new tools and services on the Internet has required no financial motivation. Wikipedia's contributors have built a powerful encyclopedia without compensation. ${ }^{136}$ Blogs have emerged on every possible subject, often (though not always) without a direct financial motive. The millions of users whose contributed content populates YouTube, MySpace, and Facebook are not compensated.

Moreover, leading Internet businesses that have profit-making at their core today had non-financial origins. Pierre Omidyar started eBay and Jerry Yang organized the link list that became Yahoo as hobbies. ${ }^{137}$ Sergey Brin and Larry Page developed Google's original search algorithm as a research project, in part to solve an academic puzzle not itself about search. ${ }^{138}$

Thus, some content innovation is relatively insensitive to the charging of a toll. For some content, permission to extract makes no difference because there's nothing to extract or the amounts are too small to feasibly collect. For others, charging a toll will have only a limited effect. For MySpace and Facebook, payment of some profits to a network provider would reduce the firm's profits but not necessarily alter the incentives of individual users. eBay, Google, and Yahoo likely would have flourished even if their founders had anticipated a "network tax" if they achieved extreme financial success.

This point has an analogue in discussions of optimal patent policy. Some innovation can be elicited without expectation of financial compensation. Some low-effort ideas will be supplied by inventors even without payment. Nonmarket financial incentives, such as government and university research grants, compensate other inventors. Moreover, innovation is often induced by nonfinancial rewards, including the thrill of discovery, satisfaction from

135 See infra Section IIl.D for further discussion.

136 Jim Giles, Internet Encyclopaedias Go Head to Head, 438 NATURE 900 (2005).

137 See Saul Hansell, Creator of the On-Line Swap Meet, N.Y. TIMES, Nov. 15, 1998, at BU2 (describing how Omidyar began eBay "on a lark"); Verne Kopytoff, It Started as 2 Guys in a Trailer; Yahoo Stands as One of Internet's Biggest Success Stories, S.F. CHRON., Feb. 28, 2005, at E1 (describing Yahoo's "hobby" origins).

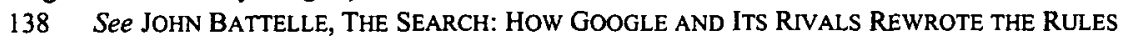
OF BUSINESS AND TRANSFORMED OUR CULTURE 65-93 (2005) (describing Stanford research project exploring backlinks that became PageRank). 
winning a competition, and the esteem of peers. Where an invention would have been made nearly as quickly without patent protection, the need for protection diminishes. ${ }^{139}$

The concern about incentives is particularly muted where the startup costs are low. ${ }^{140}$ To be sure, even such a firm may eventually require a massive infrastructure in order to achieve success. Amazon, eBay, Google, and Yahoo, like YouTube, MySpace, and Facebook, require large investments to set up the servers, connectivity, and support necessary for scale. Without a prospect of profit, investors would not make this capital available. But in this respect, content provision lacks a distinctive claim to a subsidy. Its investors are identical to those making infrastructure investments on the network side. Investments in content provider infrastructure may be dulled by the payment of a toll, and the tradeoff to be made is between content provider infrastructure and access provider infrastructure.

\section{Extraction as a Means to Increase Consumer Spillovers}

Extraction, aside from having a relatively small negative effect upon the development of some content, may be a key component of a strategy to increase consumer broadband adoption. Scholars have described broadband access as a source of positive consumer spillovers. ${ }^{141}$ Connectivity permits individuals to consume and produce creative content and fosters the development of social capital. The value may not be capturable by an access provider or content provider because it is unobservable, is beyond the grasp of feasible price discrimination, accrues partly to other users rather than the immediate consumer, or escapes the notice of the consumer and hence is not included in her willingness to pay. ${ }^{142}$ Although this economic dark matter is

139 See, e.g., Graham v. John Deere Co., 383 U.S. 1, 11 (1966) (understanding patentability standard as a way to "wee[d] out"-that is, restrict patentability to- "those inventions which would not be disclosed or devised but for the inducement of a patent"); Roberts v. Sears, Roebuck \& Co., 723 F.2d 1324,1346 (7th Cir. 1983) (Posner, J., dissenting) ("[1]f a court thinks an invention for which a patent is being sought would have been made as soon or almost as soon as it was made even if there were no patent laws, then it must pronounce ... the patent invalid.").

140 Randall Stross, The Human Touch That May Loosen Google's Grip, N.Y. TIMES, June 24, 2007, at BU3 ("The combination of low start-up costs and potentially huge profit makes [search startups] seem a reasonable bet."); see also Wu Testimony, supra note 64, at 56 (noting that for many Internet businesses, "startup costs are minimal: many successful business[es] began with just an idea and a good web site").

141 See, e.g., Frischmann \& Lemley, supra note 118, at 279 ("[T]he demand-signaling function ... does not necessarily work well when purchasers use a resource as an input ...."); id. at 293-98 (applying this argument to network neutrality).

142 Brett M. Frischmann, An Economic Theory of Infrastructure and Commons Management, 89 MiNN. L. REV. 917, 1017-20 (2005). 
difficult to quantify, careful students of the phenomena have reckoned the benefits to be large. ${ }^{143}$

There are two ways to increase the consumer benefits of broadband usage. One is the intensive margin: increasing the welfare of an existing broadband user. The other is the extensive margin: turning a nonuser into a user. The latter strategy seems promising, in part because consumer adoption of broadband in the United States has significantly lagged behind that of other countries. As of the end of 2006, U.S. adoption reached 20 connections per 100 people, fifteenth among surveyed countries and less than two-thirds the penetration of Denmark, the world leader. ${ }^{144}$

In particular, access providers could subsidize consumer adoption by charging content providers for access. ${ }^{145}$ AT\&T's pitch might be: "We're committed to pervasive broadband service, and to making access available to the millions who lack such service, by asking successful content providers to tithe a fraction of their profits, to be applied toward the provision of new consumer access." This strategy would increase consumer-side spillovers but violate a zero-price rule. The attractiveness of this proposition runs counter to the assertion, sometimes made, that a zero-price rule is necessary to preserve consumer spillovers. ${ }^{146}$

The access provider is particularly well positioned to coordinate a strategy that promotes broadband adoption. To be sure, content providers have a substantial collective incentive to increase adoption rates, in order to enjoy a larger market for their products. But any particular content provider will capture only a small part of the gain from recruiting a new broadband consumer, and the content providers, taken as a whole, will face a tragedy of the commons in dividing the total subsidy burden among themselves. Here the access provider may play a useful role by orchestrating the contributions of the different content providers.

A consumer subsidy strategy has plenty of precedents where markets are "two-sided"- that is, where a firm enables interactions between different types

143 See id. at 1017-19; Frischmann \& Lemley, supra note 118, at 296-98; see also R. Polk Wagner, Information Wants to Be Free: Intellectual Property and the Mythologies of Control, 103 COLUM. L. REV. 995 (2003).

144 See ORganisation FOR ECONOMIC CO-OPERATION AND DEVELOPMENT, OECD BROADBAND STATISTICS TO DECEMBER 2006 (2007), avalable at http://www.oecd.org/document/7/ 0,3343,en_2649_34225_38446855_1_1_1_1,00.html (reporting, as of December 2006, 19.6 connections per 100 people in the United States and 31.9 in Denmark). If the figures are normalized by household, the overall U.S. ranking changes hardly at all. One calculatıon, using June 2006 OECD data, places the United States twelfth on both a per capita and a per household basis. See Digital Future of the United States: Part IV: Broadband Lessons from Abroad: Hearing Before the Subcomm on Telecommunications and the Internet of the H. Comm. on Energy and Commerce, 110 th Cong. 17 tbl.2 (2007) (testimony of George S. Ford).

145 For an argument along similar lines, see Sidak, supra note 50, at 462 (noting that if end users pay the full cost of access, some consumers will be excluded).

146 E.g., Frischmann \& Lemley, supra note 118, at 298 (concluding that "[p]reserving Internet spillovers requires preserving network neutrality"). 
of end users. ${ }^{147}$ A difficult challenge in such markets is to set prices to attract both sides to the table. A common strategy is to combine high prices toward one side of the market with subsidization of the other. ${ }^{148}$ Game console makers offer the console at a loss ${ }^{149}$ but earn profits from royalties paid by developers; ${ }^{150}$ credit card payment systems charge merchants but subsidize consumers in the form of cash or frequent flyer miles; women pay less than men to enter certain nightclubs. ${ }^{151}$ Internet service provider NetZero adopted the same plan when it offered free dial-up Internet access to consumers but required them to watch advertising. ${ }^{152}$ Google does the same when it charges advertisers but not users of its search engine.

The lack of a zero-price restriction upon the pricing behavior of credit card payment systems, video game consoles, and other platform providers promotes widespread adoption of each technology. Where, as with broadband service, an access charge for content providers is not likely to be entirely passed on by content providers to the customer, ${ }^{153}$ a zero-price rule can have an inhibitory effect upon adoption. That is not to say that a zero-price rule is necessarily inimical to broadband access. The present point is simply that a zero-price rule is not essential to a robust broadband access policy.

\section{Contracting into Decentralized Innovation}

Resting the argument for a broad-based zero-price rule on extraction concerns encounters a further problem. Advocates of zero-price regulation rightly emphasize the value and importance of decentralized content innovation. But there is reason to expect that even if access providers have a measure of control over the path of complementary content innovation, ${ }^{154}$ they will use that control to promote decentralized innovation. By "contracting into"

147 For an introduction, see Rochet \& Tirole, supra note 5.

$148 I d$. at 659 (noting, as examples, giving away Acrobat reader to make money from writers, giving away newspapers to increase advertising, and below-cost video game consoles).

149 See, e.g., Press Release, iSuppli, PlayStation 3 Offers Supercomputer Performance at PC Pricing (Nov. 16, 2006), available at http://www.isuppli.com/news/default.asp?id=6919 (reporting result of teardown analysis of PlayStation 3 game console). The premium model of the console has an estımated materials cost of $\$ 840$ and a suggested retail price of $\$ 599$. The basic model has an even wider discrepancy.

150 DaVid S. EVANS ET AL., INVISIBle EngINES: How Software Platforms Drive INNOVATION AND TRANSFORM INDUSTRIES 135 (2006) (reporting $\$ 7$ per unit royalty for Xbox games made by third parties).

151 Lauren Collins, On the Docket: Hey, La-a-a-dies!, NEw YORKER, Aug. 6, 2007, at 22 (describing an equal protection challenge to lower admission fees for women at New York clubs).

152 NetZero later moved to a pricing structure based upon user fees.

153 If the access charge to the content provider is passed through entirely to the customer, then the policy has no effect on adoption.

154 As opposed to content that competes with a legacy business, as discussed supra in Section II.B. 
decentralized innovation, ${ }^{155}$ an access provider will implement, as a private matter, the same basic arrangement that zero-price advocates seek through government intervention.

The flourishing of attractive content is in an access provider's interest because it raises the surplus that can be extracted by the access provider. One option is for an access provider to attempt to make attractive content on its own. This strategy is likely to fail because innovative content ideas are widely dispersed. ${ }^{156}$ Someone will invent PageRank, ${ }^{157}$ but any particular access provider is unlikely to come up with that innovation even if it exerts considerable effort. A large incumbent may find it particularly difficult to develop innovative content in-house. Its culture may resist new approaches, and its relatively flat pay structure makes it difficult to provide large rewards to financially motivated individual innovators. The problem is worsened if the access provider is an incompetent steward and exercises control in an irrational or arbitrary way. ${ }^{158}$

The dispersed nature of innovation implies the failure of in-house content production. Decentralization is necessary. But it does not follow that government-mandated decentralization will increase the production of innovative content. Even if a content provider lacks a regulatory entitlement to retain a certain level of rewards from its innovation, the access provider has a strong incentive to furnish those rewards. Where the interests of the access provider and the content provider can be aligned in this fashion, the initial distribution of regulatory entitlements does not matter. This is a familiar argument, essentially the Coase theorem in a dynamic setting, ${ }^{159}$ well captured by the explicitly Coasean analysis of Owen and Rosston ${ }^{160}$ and the "internalizing complementary efficiencies" baseline described by Farrell and Weiser. $^{161}$

155 Cf. Stuart Minor Benjamin, Spectrum Abundance and the Choice Between Private and Public Control, 78 N.Y.U. L. REV. 2007 (2003); Robert P. Merges, Contracting into Liability Rules: Intellectual Property Rights and Collective Rights Organizations, 84 CAL. L. REV. 1293 (1996).

156 For an introduction, see SCOTCHMER, supra note 120 (collecting and evaluating literature); Peter S. Menell \& Suzanne Scotchmer, Intellectual Property, in 2 HANDBOOK OF LAW AND ECONOMICS 1473 (A. Mitchell Polinsky \& Steven Shavell eds., 2008).

157 PageRank, the "heart" of Google search software, "relies on the uniquely democratic nature of the web by using its vast link structure as an indicator of an individual page's value." Google Technology, http:/www,google.com/technology (last visited Apr. 18, 2008); see also Sergey Brin \& Lawrence Page, The Anatomy of a Large-Scale Hypertextual Web Search Engine, 30 COMPUTER NETWORKS \& ISDN SYS. 107 (1998) (describing PageRank).

158 Farrell \& Weiser, supra note 43, at 114-17.

159 See, e.g., Guido Calabresi, Transaction Costs, Resource Allocation, and Liability RulesA Comment, 11 J.L. \& ECON. 67 (1968) (acknowledging applicability of Coase theorem to dynamic entry decisions).

160 See Owen \& Rosston, supra note 49, at 167-68 (suggesting the utility of a Coasean perspective).

161 Farrell \& Weiser, supra note 43; cf. Edmund W. Kitch, The Nature and Function of the Patent System, 20 J.L. \& ECON. 265 (1977). 
There are theoretical reasons to think that the dynamic Coase theorem does not always hold. For example, a content provider might worry that once it sinks the costs of application development, it will be subject to "holdup," or expropriation of its profits by the access provider. The holdup problem is not limited to content providers. For example, an access provider's investment in capacity makes later content development possible. When it comes time to divide the surplus jointly created by the new capacity and the new content, the access provider's previously sunk costs are not part of the bargain. ${ }^{162}$ This dilemma of sequential innovation creates a significant difficulty for access providers-for example, Verizon, during its continuing fiber-to-the-home rollout ${ }^{163}$-seeking to recover fixed costs expended to develop a joint innovation. ${ }^{164} \mathrm{~A}$ zero-price rule worsens that cost recovery problem.

How well do access providers contract into decentralized innovation? Direct evidence on this question is lacking. ${ }^{165}$ The technical ability of an access provider to engage in extraction is only now emerging, and so we lack a track record of negotiations between access providers and content providers succeeding or failing. It has not been established, moreover, whether an access provider can simply precommit to a menu of charges that varies depending upon the size and success of the content provider, a step that would reduce the holdup problem. The absence of direct evidence is a reason to resist ambitious regulation, such as a zero-price rule.

Evidence from other industries suggests that the holdup problem is not severe. Recall, for example, the video game developer's royalty payments to the console maker. ${ }^{166}$ Movie studios use a variety of contractual instruments to coordinate sequential investments by writers, producers, and actors. ${ }^{167}$ Codevelopment relationships ameliorate, as a practical matter, the theoretical

162 For example, suppose that the access provider makes a capacity investment at a cost of 10 , and then a content provider develops innovative content, possible only as a consequence of the earlier capacity investment, at a cost of 5 . The benefit created by the two investments is 20 . The access provider can anticipate the size of this benefit but not its source. If the two bargain after all costs are sunk, and the two divide the gain evenly, each receives 10 , and the investment will proceed. If the access provider's costs are slightly higher, then the access provider will not invest in the first place, and the socially valuable innovation will not be produced. Note that if the content provider can be identified prior to the access provider's investment, the problem is reduced, for in that case the access provider will insist that the content provider help cover those costs.

163 Arshad Mohammed, Verizon Lays It on the Line: CEO Sticks By Costly Rollout of FiberOptic Network, WASH. POST, Feb. 1, 2006, at D1.

164 See SCOTCHMER, supra note 120, at 135-40.

165 For a recent statement emphasizing the absence of demonstrated harm, see Ex Parte Filing, U.S. Dep't of Justice, In re Broadband Industry Practices, 22 F.C.C.R. 7894 (Apr. 16, 2007) (No. 07-52), available at http://www.usdoj.gov/atr/public/comments/225767.pdf.

166 Console makers employ a mix of "make" and "buy" strategies. Sony and Microsoft have worked with outside vendors for the most part. Nintendo has made games on its own, though this is changing. Martin Fackler, Putting the We Back in Wii, N.Y. TIMES, June 8, 2007, at BCl. Some games are made for multiple consoles, while others are exclusive to one console.

167 See, e.g., Victor P. Goldberg, The Net Profits Puzzle, 97 COLUM. L. REV. 524 (1997). 
effect of holdup in automobile manufacturing ${ }^{168}$ and other industries. ${ }^{169}$ Some firms, such as Intel, promote complementary innovation by making clear commitments to preserve the profitability of complementary markets. ${ }^{170} \mathrm{~A}$ practically-minded literature provides advice about how best to "procure innovation" from outside suppliers. ${ }^{171}$

There are counterexamples, in which privately arranged decentralization has failed. For example, only after the Carterfone decision, and the accompanying reduction in AT\&T's control of innovations complementary to ordinary telephone service, did applications such as modems and fax machines emerge. There exist historical examples in which a single firm with broad patent protection has controlled an industry, and proved to be a poor orchestrator of later improvements. ${ }^{172}$ The relevance of these counterexamples is limited by a common feature: the presence of a single dominant firm with control over an industry. ${ }^{173}$ (Nor do all dominant firms threaten complementary innovation, as the Intel counterexample demonstrates.) In broadband access provision, by contrast, no single firm has anything like that level of control. No provider has a U.S. market share larger than 25 percent, and most have much less. The relative unimportance of each access provider increases the competitive pressure to make good decisions about complementary innovation, and reduces the likelihood that any single provider's suboptimal decision will have an adverse effect. ${ }^{174}$

168 Susan Helper et al., Pragmatic Collaborations: Advancing Knowledge While Controlling Opportunism, 9 INDUS. \& CORP. CHANGE 443 (2000). Automobile manufacturing is the source of the most famous case of holdup in the literature, the negotiations between General Motors and a key supplier, Fisher Body. Whether that example actually reflects holdup is subject to doubt. See Ronald Coase, The Conduct of Economics: The Example of Fisher Body and General Motors, 15 J. ECON \& MGMT. STRATEGY 255 (2006).

169 See Charles F. Sabel \& Jonathan Zeitlin, Neither Modularity or Relational Contracting: Inter-Firm Collaboration in the New Economy, 5 ENTERPRISE \& SOC'Y 388 (2004) (discussing "the profusion of innovative disciplines and practices of co-design such as simultaneous engineering, benchmarkıng, co-location of personnel, problem-solving teams, processual quality standards, and the like").

170 See Gawer \& Henderson, supra note 5 (providing a detalled account of Intel's efforts to preserve innovation in complementary markets).

171 Luis Cabral et al., Procuring Innovations, in HANDBOOK OF PROCUREMENT 483 (Nicola Dimitri et al. eds., 2006) (suggesting principles for purchase of innovative goods by public and private entities).

172 See Robert P. Merges \& Richard R. Nelson, On the Complex Economics of Patent Scope, 90 COLUM. L. REV. 839 (1990) (offering examples from electrical lighting, automobile, airplane, and radio industries).

173 In addition, some really amount to anticompetitive suppression of substitutes rather than poor strategy in the promotion of complements.

$174 C f$ Bresnahan \& Greensten, supra note 5 (making a similar point in the context of "divided technical leadership"). Indeed, an access provider's decision might well have no substantial effect, due to fragmentation among access providers, an effect discussed supra in Subsection II.B.1. If a content provider can achieve scale without access to a particular access provider's customers, the access provider has little effect on innovation. 


\section{Conclusion}

The merits of a zero-price rule that protects content providers generally cannot be sustained. Exclusion concerns are addressed by antitrust law, with the caveats noted in Part II. Extraction grounds fail to justify zero-price regulation for the reasons discussed in Part III, including substitution to indirect extraction, the availability of nonfinancial rewards for content innovation, the virtues of an extraction-reliant strategy for increasing broadband adoption (and, as many have noted, for encouraging infrastructure development), and the absence of evidence that privately negotiated decentralization is infeasible.

This Article's typology of exclusion and extraction, and accompanying analysis of each strategy, are useful tools to assess other claims that a powerful firm has the ability and incentive to limit competition and innovation. Consider, for example, Google, currently the most powerful content provider. The incentives of content providers have been neglected, compared to the extensive recent scrutiny of access providers. A shift in attention is appropriate in part because, as explained in Part II, exclusion of a content provider, an important focus of network neutrality proposals, is of primary benefit to a rival content provider.

Google is a major infrastructural resource that possesses the major features that have traditionally given rise to common carrier regulation. Moreover, Google's bargaining position does not suffer from the market fragmentation that besets an individual access provider, making it a more likely extractor than AT\&T or Comcast, extraction that could be undertaken with respect to access providers or complementary content businesses.

As for exclusion, a risk arises where a complementary content business has a contractual or ownership relationship to Google's core search business, and there are incentives to favor that content over rivals in Google's search results. A full analysis is beyond the scope of this Article, but as analysts of network neutrality turn toward the analogous question of search neutrality, three lessons from Part II are particularly relevant.

First, the degree of ownership matters. Anticompetitive favoritism is rendered less visible and less amenable to antitrust enforcement when it is masked within the firm. Google's steady accretion of content affiliates, such as YouTube, news, maps, and financial information, provides a greater opportunity for anticompetitive favoritism. The effect of ownership is compounded by a second factor: the technology of favoritism. Network neutrality concerns have become more important as the technology of traffic differentiation has improved. Search neutrality will become more important as search results become easier to manipulate-for example, with "universal search," in which Google's familiar list of ten blue links is augmented with 
information from its affiliates. ${ }^{175}$ As PageRank cedes ground to Google's own editorial choices, the opportunity for favoritism increases.

Third, social production is particularly vulnerable when rival content offers a superior mechanism for extraction, and alternative mechanisms for collecting surplus (such as charging consumers) are unavailable. As an example, consider Google's newest content affiliate, Knol, still under development as of April 2008. ${ }^{176} \mathrm{Knol}$ is a proposed for-profit alternative to Wikipedia, in which authors and Google share advertising dollars. Knol gives Google a revenue stream that it misses out on when consumers use Wikipedia instead. As a consequence, Google has an incentive to steer traffic to Knol, even if users prefer Wikipedia. ${ }^{177}$ The resulting decrease in Wikipedia traffic might reduce participation in, and hence the quality of, Wikipedia. ${ }^{178}$

Whether anything comes of the Knol initiative, Google's foray does suggest that the "Wikipedia gap" discussed in Part II is not merely theoretical. Nevertheless, even though the narrower case of socially produced content presents a relatively stronger argument for regulation, implementing such regulation in practice requires a better understanding of the circumstances under which alternative mechanisms protect social production. For example, as explained in Part II, effective price discrimination among consumers makes regulatory protection unnecessary, by providing an alternative mechanism by which an access provider can harvest the available surplus, rather than excluding social production. Moreover, other complementors of the socially produced content may be able to engage in counterstrategies that reduce the utility of regulation.

The vulnerability of social production is a general issue. It recurs, for example, in the ongoing high-stakes battle between Linux and Microsoft. Microsoft, a market producer, has secured patents pertaining to operating

175 comScore reported that during a one-week sample period in January $2008,17 \%$ of Google results included universal search, and more than half of users saw a universal search result. Kevin Ryan, Uncovering the Real Universal Search, SEARCH ENGINE WATCH, Mar. 19, 2008, http://searchenginewatch.com/showPage.html?page=3628796.

176 Posting of Udi Manber, VP Engineering, to Official Google Blog, http://googleblog. blogspot.com/2007/12/encouraging-people-to-contribute.html (Dec. 13, 2007, 18:01:00 EST).

177 See Nate Anderson, Google to Wikipedia: "Knol" Thine Enemy, ARS TECHNICA, Dec. 14, 2007, http://arstechnica.com/news.ars/post/20071214-google-to-wikipedia-knolthine-enemy.html ("II]t's clear that Google really wants to be in control . . . And it can offer something that Wikipedia, et al., cannot: cash."). Interestingly, Google might have an incentive to privilege its affiliate even if this incentive is missing, because the popularity of Knol results are easier to measure. Cf. Danny Sullivan, Google Knol-Google's Play to Aggregate Knowledge Pages, SEARCH ENGNE LAND, Dec. 13, 2007, http://searchengineland.com/071213-213400.php.

178 Posting of Duncan Riley to TechCrunch, http://www.techcrunch.com/2007/12/14/googleknol-a-step-too-far (Dec. 14, 2007) (describing Knol as "direct challenge to Wikipedia" and arguing that "[i]f Wikipedia is replaced in the first few results on Google with pages from Knol, Wikipedia traffic will decrease, and possibly as a consequence so will broader participation on Wikipedia"). 
system functionality that Linux might infringe. ${ }^{179}$ Linux, the product of social production, has not secured a comparable patent portfolio to threaten Microsoft. This has created a potential strategic disadvantage for Linux, in which it is unable to enforce mutual deterrence with Microsoft. ${ }^{180}$ Extending the familiar analogy of nuclear deterrence, in which patentholders engage in mutual abeyance, rather than launching patent infringement suits, the question is whether and when a well-equipped ally will commit to extend its protective umbrella. ${ }^{181}$ This Article provides a first step toward a better understanding of the strategic interaction between social production and market production. Identifying the extent and availability of credible counterstrategies is a promising area for future research.

179 Daisuke Wakabayashi \& Jim Finkle, Microsoft Says Open Source Violates 235 Patents, REUTERS, May 15, 2007 (reporting Microsoft's contention that open-source software violates 235 company patents and intention to seek licensing fees).

180 See Roger Parloff, Microsoft Takes on the Free World, FORTUNE, May 28, 2007, at 76.

181 Matthew Broersma, Google Joins Open-Source Patent Network, ZDNET NEws, Aug. 8, 2007, http://news.zdnet.com/2100-9595_22-6201407.html; Martyn Williams, IBM, Sony, Red Hat Join Others in Linux Patent Venture, INFOWORLD, Nov. 10, 2005, http://www.infoworld.com/article/ 05/11/10/HNlinuxpatent_1.html. 
